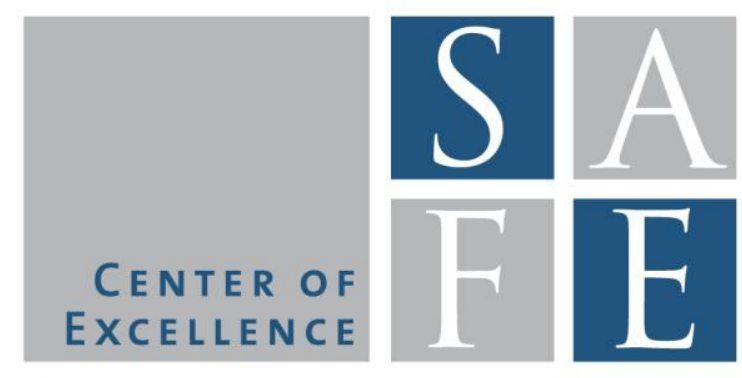

WORKING PAPER SERIES

Fabio Castiglionesi - Fabio Feriozzi - Gyöngyi Lóránth - Loriana Pelizzon

\title{
Liquidity Coinsurance and Bank Capital
}

SAFE Working Paper Series No. 45

Center of Excellence SAFE Sustainable Architecture for Finance in Europe A cooperation of the Center for Financial Studies and Goethe University Frankfurt 


\section{Non-Technical Summary}

Liquidity risk is one of the main risk factors for institutions such as banks that base their activities on the transformation of short term liquid liabilities into long term illiquid assets.

Banks have at their hands different strategies to cope with liquidity risk: hold liquid reserves (self-insurance), utilize bank capital (risk-sharing) and participate in the interbank market (coinsurance). Due to the double nature of the liquidity risk (partly diversifiable and partly non-diversifiable), these three strategies with their pros and cons should not be considered mutually exclusive. The exposure to diversifiable liquidity risk components can be effectively approached by operating on the interbank market that, despite its OTC nature based on fixed linkage between a limited number of players, allows to mitigate the asymmetric liquidity shocks. Unfortunately, operating on the interbank market is totally ineffective when facing symmetric shocks. The hold of short-term maturity reserves (diverting liquidity from more profitable long term investments) and the withholding of a part of the payouts to bank capital holders (reducing dividend payments) represent two costly but unavoidable solutions to face symmetric, thus non-diversifiable, liquidity risk components.

By modeling the assets and liability structure of two banks in a way that, due to their funding and investment strategies, are both exposed to diversifiable and non-diversifiable liquidity risks, we create a scope for the use of the interbank market and the use of bank capital as risk-sharing devices. We infer that the optimal capital structure crucially depends on the extent to which the liquidity risk is diversifiable. In particular, bank capital eventually decreases when the probability of an asymmetric shock increases or, correspondingly, bank capital increases when non-diversifiable liquidity risk (namely the probability of symmetric shocks) increases.

We tested our hypothesis on the basis of a large sample of US commercial banks (quarterly panel from Q1 1995 to Q2 2007); the tests were replicated for the sake of robustness on the grounds of a panel that includes the global financial crisis of 2007-2009 (quarterly panel from Q1 1995 to Q4 2012) and on the grounds of European and Japanese commercial banks (yearly data from 2005 to 2010).

We built a set of econometric indicators aimed at measuring: i) relations between book value of the capital and a proxy of the liquidity risk's diversification; ii) time-series variation of the first principal component of banks' deposits and non-diversifiable shocks on deposits; iii) conditional correlation between a bank's interbank market activity and its capital.

The first measure is based on the main idea that banks with larger interbank positions have easier access to other banks, thus better ex-ante coinsurance opportunities. It provides evidence both at aggregate and bank level of the risk-sharing role of bank capital. In fact, at aggregated level, bank capital ratios have a clear upward trend while aggregated interbank activities are declining. This finding is consistent with the risk-sharing function of bank capital that predicts a negative correlation between capital and diversifiable liquidity risk. The second indicator, consistent with a risk sharing function of bank capital, shows that the percentage of the total variation of deposits explained with the first principal component has a positive and significant correlation with aggregate capital ratios and a negative correlation with interbank activities. The third measure shows strong evidence of a negative relationship between bank capital and interbank market activities.

Concluding, we consider that our findings very supportively underline the important role played by bank capital in managing liquidity risk; as well as the role of liquidity risk and its double diversifiable / non-diversifiable nature in affecting the way liquidity and capital are managed within a bank in the medium and long term horizon. 


\title{
Liquidity Coinsurance and Bank Capital ${ }^{*}$
}

\author{
Fabio Castiglionesi ${ }^{\dagger} \quad$ Fabio Feriozzi ${ }^{\ddagger} \quad$ Gyöngyi Lóránth ${ }^{\S}$ \\ Loriana Pelizzon
}

\begin{abstract}
Banks can deal with their liquidity risk by holding liquid assets (self-insurance), by participating in interbank markets (coinsurance), or by using flexible financing instruments, such as bank capital (risk-sharing). We use a simple model to show that undiversifiable liquidity risk, i.e. the liquidity risk that banks are unable to coinsure on interbank markets, represents an important risk factor affecting their capital structures. Banks facing higher undiversifiable liquidity risk hold more capital. We posit that empirically banks that are more exposed to undiversifiable liquidity risk are less active on interbank markets. Therefore, we test for the existence of a negative relationship between bank capital and interbank market activity and find support in a large sample of U.S. commercial banks.
\end{abstract}

JEL Classification: G21.

Keywords: Bank Capital, Interbank Markets, Liquidity Coinsurance.

*We thank Angelo Baglioni, Christa Bouwman, Fabio Braggion, Max Bruche, Hans Degryse, Mark Flannery, Robert Hauswald, Vasso Ioannidou, Jose Jorge, Enisse Kharroubi, Christian Laux, Marcella Lucchetta, Joao Santos, Steven Ongena, Wolf Wagner and seminar participants at University of Vienna, Norwegian Business School, University of Geneva, University of Bologna, Deutsche Bundesbank Conference "Liquidity and Liquidity Risk", ELSE-UCL Workshop in "Financial Economics: Markets and Institutions", Frias-CEPR Conference "Information, Liquidity and Trust in Incomplete Financial Markets", Fourth Swiss Winter Conference on Financial Intermediation, Fourth Bank of Portugal Conference on Financial Intermediation, MoFiR workshop, and Eighth FIRS Conference for helpful comments. We thank Mario Bellia for excellent research assistance. The usual disclaimer applies.

${ }^{\dagger}$ CentER, EBC, Department of Finance, Tilburg University. E-mail: fabio.castiglionesi@uvt.nl.

${ }^{\ddagger}$ CentER, Department of Finance, Tilburg University. E-mail: f.feriozzi@uvt.nl.

$\S$ University of Vienna and CEPR. E-mail: gyoengyi.loranth@univie.ac.at.

`University Ca’ Foscari of Venice and SAFE-Goethe University Frankfurt. E-mail: pelizzon@safe.unifrankfurt.de. 


\section{Introduction}

The management of liquid resources is an important concern for banks. They typically transform short-term liquid liabilities into long-term illiquid assets and are therefore exposed to a substantial degree of liquidity risk. A simple way to tackle this uncertainty is to hold liquid reserves, which amounts to self-insuring against the occurrence of a liquidity shock. This is costly for banks, as they could instead invest in more productive illiquid or risky assets. Alternatively, banks can participate in interbank markets, where they can exchange resources with other banks. Interbank markets, however, also represent a partial solution, for at least two reasons. First, part of the liquidity risk is likely to be systematic and, by definition, impossible to insure. Second, interbank markets typically operate over the counter and are based on a limited number of pre-established connections. Even idiosyncratic liquidity shocks may be impossible to coinsure in the absence of such pre-established connections. ${ }^{1}$ Since payouts to holders of bank capital are not fixed obligations, bank capital also offers an opportunity to deal with liquidity risk: by adjusting the payouts to bank capital holders, banks can transfer part of the liquidity uncertainty to capital investors. This liquidity risk-sharing function of bank capital, however, also comes at a cost since raising capital is itself costly for banks. ${ }^{2}$

This paper analyzes the interplay between bank capital, interbank market activity, and banks' portfolio choice. In particular, we study to what extent the presence of an interbank market affects banks' incentives to hold (costly) capital and to invest in liquid assets. We first introduce a theoretical model where banks face uncertain liquidity needs and show that bank capital has a negative relation with the ex-ante coinsurance opportunities offered by interbank markets. Intuitively, banks with limited coinsurance opportunities face higher liquidity risk, and therefore find it optimal to hold more capital. We then proceed to show that this prediction finds strong support in a large sample of U.S. commercial banks.

We model two banks that collect deposits from risk-averse depositors and capital from risk-neutral investors. Banks invest the collected resources into short-term liquid assets (a storage technology), and long-term illiquid assets. The liquidity needs of banks are

\footnotetext{
${ }^{1}$ Another reason why interbank markets might offer limited coinsurance opportunities is the presence of moral hazard or adverse selection problems (see Bhattacharya and Gale [8]).

${ }^{2}$ Alternatively, bank capital is often considered to either act as a buffer protecting against solvency shocks, or mitigate risk-taking incentives (see, among others, Brusco and Castiglionesi [10], and Morrison and White [25]).
} 
uncertain. In particular, liquidity shocks are either asymmetric, in which case one bank has high liquidity needs and the other has low liquidity needs, or symmetric, in which case both banks have high liquidity needs. Banks participate in an interbank market which allows them to coinsure against asymmetric liquidity shocks. The liquidity risk that can be coinsured in the interbank market is called diversifiable (liquidity) risk. However, the interbank market is of no use in the case of symmetric liquidity shocks. The liquidity risk that cannot be coinsured in the interbank market is referred to as undiversifiable (liquidity) risk. $^{3}$

The presence of undiversifiable liquidity uncertainty creates a scope for the use of bank capital as a risk-sharing device. Indeed, banks can rely on interbank markets only to deal with the diversifiable liquidity risk, and have to use bank capital to deal with the undiversifiable risk. Because raising bank capital is costly, banks would hold no capital were the liquidity risk fully diversifiable. More generally, an important insight from the analysis is that the optimal capital structure crucially depends on the extent to which the liquidity risk is diversifiable. In the model, it is the probability that banks are hit by asymmetric liquidity shocks that captures the diversifiability of the liquidity risk, and we show that bank capital eventually decreases as the probability of asymmetric shocks increases. Equivalently, bank capital eventually increases as the undiversifiable liquidity risk (i.e., the probability of the symmetric shock) increases. ${ }^{4}$

In the empirical part of the paper we test this prediction in a large sample of U.S. commercial banks by relating the book value of bank capital with a proxy of the diversifiability of liquidity risk. ${ }^{5}$ We take banks' activity on interbank markets, measured by the sum of interbank lending (assets) and borrowing (liabilities) positions, as our empirical proxy of diversifiable liquidity risk. As interbank assets comprise deposits at other

\footnotetext{
${ }^{3}$ We stress the fact that the symmetric liquidity shocks do not necessarily correspond to an aggregate, market-wide shock. They can also be undiversifiable because of bank-specific reasons such as, for example, a limited access to the interbank market (Cocco et al. [12] provide evidence of the relevance of preestablished relationships in determining interbank activity).

${ }^{4}$ These relationships, however, are not necessarily monotonic. Monotonicity is nevertheless guaranteed when the liquidity risk is sufficiently diversifiable. We argue that in developed economies this condition generally holds.

${ }^{5}$ The reason to focus on book value is that, while detailed measures of interbank market activity are available for individual commercial banks, the market values of equity are available mostly for bank holding companies, where the commercial activity is often combined with other activities, such as investment banking, merchant banking, insurance, etc.
} 
banks that can be drawn down to respond withdrawals in a given bank, together with interbank borrowing they constitute a proxy of co-insurance opportunities provided by interbank markets. The idea is that banks with larger interbank positions have greater ease of access to other banks, and therefore have better ex-ante coinsurance opportunities. We later show that our results still holds when we split the sample based on whether a bank is a net lender or borrower in the market.

We use the Statistics on Depository Institutions (SDI) database, maintained by the Federal Deposit Insurance Corporation (FDIC), to retrieve information on banks' Call Reports. We build a quarterly panel dataset spanning from the first quarter of 1995 to the second quarter of 2007. We do not include the crisis period because of the extreme events, which occurred after the second half of 2007, which might have introduced unusual dynamics both in interbank activity and bank capital. We however run a robustness check where we also consider the crisis period. The interbank activity we focus on consists of unsecured interbank lending and borrowing. This does not include activities on the Repo and Fed Fund markets for two reasons: (1) these markets are also used by nonbanking institutions while our focus is on banks; (2) their inclusion in the regression framework does not affect our result. As for capital, we adopt a broad definition consisting of the book value of total equity, which includes both common and preferred stock.

We present both aggregate and bank-level evidence of the risk-sharing role of bank capital. At the aggregate level bank capital ratios have a clear upward trend in the U.S. over our sample period, while aggregate interbank activity has been declining. ${ }^{6}$ Their correlation is negative and statistically significant. This is consistent with the risk-sharing function of bank capital that predicts a negative correlation between capital and diversifiable liquidity risk. In this sense we provide an explanation for the bank capital build up that does not rely on banks increased profitability over the sample period. According to this pecking-order view of bank capital, banks would retain a large portion of their earnings to finance future activities, and capital would therefore passively rise in periods of increased profitability. Consistently with Berger et al. [7], we instead document that banks seem to actively

\footnotetext{
${ }^{6}$ Aggregate capital ratios are defined as the sum of total equity capital normalized by the sum of banks' total assets. In a similar way, aggregate interbank activity is defined as the sum of interbank lending and borrowing positions normalized by the sum of banks' total assets.
} 
manage their capital structures, reacting to a changing environment. In particular, we stress the role of the changing nature of the liquidity risk.

At the aggregate level we also examine a measure of undiversifiable liquidity risk. We consider seven non-overlapping periods of eight quarters between 1995Q1 and 2008Q4 and, for each period, we extract the first principal component of deposits. This factor captures the existence of a common source of time-series variation in banks' deposits, and can therefore be used to assess the degree of undiversifiability of banks' shocks to deposits. In particular, we look at the percentage of total variation of deposits that is explained by the first principal component, and we call this quantity the "commonality of deposits". Again consistently with a risk-sharing function of bank capital, we find that the commonality of deposit has been increasing over time and displays a positive and significant correlation with aggregate capital ratios. The commonality of deposits is also found to have a negative and significant correlation with banks' interbank activity, consistently with the former measuring undiversifiable liquidity risk, and the latter measuring diversifiable liquidity risk.

We then present bank-level evidence by using a regression approach. In particular, we estimate the conditional correlation between a bank's interbank market activity and its capital, controlling for several possible confounding factors and including both bank fixed effects and time dummies. We find strong evidence of a negative relationship between bank capital and interbank market activity. This relationship is also detected in the cross section of banks. In particular we find a negative and significant cross-sectional relationship between bank capital and interbank activity in 40 quarters out of the 50 included in the sample period. We run several robustness checks to assess the reliability of our findings, and we also replicate our results in a sample of European and Japanese commercial banks using yearly data from 2005 to 2010. Overall, we consider our evidence as very supportive of the view that an important role of bank capital is to help manage liquidity risk.

Notice that these empirical findings would be difficult to rationalize with other theoretical explanations. For example, consider the incentive function of bank capital: to the extent that bank capital provides an incentive to avoid excessive risk taking, more capital should translate into lower insolvency risk, and should result in easier access to the interbank market. This in turn would imply a positive relationship between the level of bank capital and interbank activity, at least for banks that are net borrowers.

It is important to stress that the main goal of the paper is to look at how the diversifi- 
ability of liquidity risk affects the way liquidity and capital are managed within a bank in the medium/long term horizon. The objective of our paper is neither to focus on the functioning of the interbank market during the crisis nor to study banks' overnight liquidity management. The novelty of our approach comes from looking at the interplay between banks' capital holding and interbank market activity. To the best of our knowledge, neither the theoretical nor the empirical banking literature have explicitly studied this relationship so far.

Our paper is related to both theoretical and empirical works in banking. On the theory side, the paper closest to ours is Gale [20]. He also considers the risk-sharing role of bank capital but, contrary to us, his analysis focuses on regulatory aspects without providing an analysis of the relationship between interbank market activity and bank capital. For this purpose, Gale [20] considers spot interbank markets as a way to coinsure against liquidity shocks. Contrary to him, and similarly to Allen and Gale [5], and Castiglionesi et al. [11], we model the interbank market as a device to decentralize the first-best allocation. In particular, we assume that banks make ex ante arrangements to coinsure themselves. However, both in Allen and Gale [5] and Castiglionesi et al. [11] bank capital is ignored, hence we are able to analyze the interaction between the liquidity insurance provided by the interbank market and by bank capital. ${ }^{7}$

On the empirical side, our paper relates to two different strands of the literature: one on bank capital and the other on interbank markets.

Regarding bank capital, most of the attention is on bank holding companies (BHC) rather than commercial banks. Gropp and Heider [22] study the determinants of BHC's capital structure. They find that deposit insurance and capital regulation do not seem to have a significant impact on banks' capital structure and the most important determinants are instead time-invariant bank fixed effects. To the extent that diversifiable liquidity risk is a persistent bank characteristic, it might be responsible for at least some of the explanatory power of bank fixed effects. In order to explain the main causes of the capital

\footnotetext{
${ }^{7}$ There is also an extensive theoretical literature on capital regulation based on the incentive function of bank capital. The results are not conclusive because while bank capital requirements usually decrease risk, the reverse is also possible (see Kim and Santomero [24], Furlong and Keeley [19], Gennotte and Pyle [21], Besanko and Kanatas [9] and Hellman et al. [23]). Among the recent contributions, Diamond and Rajan [14] rationalize bank capital as the trade off between liquidity creation, costs of bank distress and the ability to force borrower repayments. Allen, Carletti and Marquez [4] analyze the role of market discipline as a rationale to hold bank capital.
} 
build-up of large U.S. banks in the 1990s, beyond their increased profitability, several arguments have been put forward. Flannery and Rangan [15] argue that the main reason was the increased market discipline due to legislative and regulatory changes, resulting in the withdrawal of implicit government guarantees. Berger et al. [7] show that BHC actively manage their capital ratios in response to the perceived risk exposure (such as default risk of banks customers, earnings volatility, etc.). We contribute to this literature showing that the documented bank capital build-up of commercial banks might be due to an increased undiversifiability of the liquidity risk.

Regarding the interbank market, Cocco et al. [12] provide evidence of how pre-existing interbank relationships represent an important determinant of the ability to access the Portuguese interbank market. Studies in the U.S. usually focus on the Fed Funds market. Furfine ([16], [17], and [18]) analyzes banks' screening and monitoring activity in the Federal Funds market, and the behavior of this market during Russia's sovereign default. Afonso et al. [3] examine the impact of the bankruptcy of Lehman Brothers on the functioning of the Federal Funds market. They argue that while banks certainly became more restrictive in terms of the counterparties they lent to, there never was a complete collapse of this market.

The remainder of the paper is organized as follows. Section 2 presents the theoretical model. Section 3 analyzes the optimal risk-sharing allocation and discusses how it can be decentralized in the presence of interbank markets. Section 4 characterizes the efficient allocation and analyzes how bank capital (section 4.1) depends on the diversifiable liquidity risk. Section 5 presents the data (section 5.1) and the results on the aggregate evidence (section 5.2) and on the panel regressions (section 5.3). Section 6 concludes. Appendix A contains the proofs, and Appendix B reports a detailed description of the variables, together with their unconditional correlations.

\section{Theory: Sharing the Liquidity Risk}

The theoretical model is similar to Gale [20], and provides a rationale for the use of bank capital based on liquidity risk sharing. There are three dates $(t=0,1,2)$ and a single good available at each date for both consumption and investment. Two assets are available for investment: a short-term or liquid asset that matures in one period with a return of one, and a long-term or illiquid asset that requires two periods to mature and delivers a return 
$R>1$. The short-term asset represents a storage technology, while the long-term asset captures long-term productive opportunities. For simplicity, they are called the short and, respectively, the long asset. Clearly, the choice of a portfolio of assets reflects a trade-off between returns and liquidity.

We consider two banks $i=A, B$, and two groups of agents. The first group is a continuum of risk-neutral agents that we call investors. They are endowed with a large amount of the consumption good at $t=0$ and nothing at $t=1,2$. Investors cannot consume a negative amount at any time and discount future consumption. More precisely their utility is

$$
\rho_{0} c_{0}+\rho_{1} c_{1}+c_{2},
$$

where $\rho_{0}>R$, and $\rho_{0}>\rho_{1}>1$. This captures in a simple way that obtaining resources from investors at $t=0$, against the promise of future repayments, is costly. In fact, to postpone consumption until $t=1$ investors require a return of $\rho_{0} / \rho_{1}>1$, which is above the return of the liquid asset. Similarly, to postpone consumption until $t=2$ investors require a return of $\rho_{0}>R$, which exceeds the return of the illiquid asset.

The second group is given by risk-averse agents that we call depositors. They are endowed with 1 unit of the consumption good at $t=0$, and nothing at $t=1,2$. Following Diamond and Dybvig [13], depositors can be of two types: early consumers who only value consumption at $t=1$, or late consumers who only value consumption at $t=2$. The type of an agent is not known at $t=0$. When consumption is valuable, the agent's utility is $u(c)$, where $u: \mathbb{R}_{+} \rightarrow \mathbb{R}$ is continuously differentiable, strictly increasing and concave, and satisfies the Inada condition $\lim _{c \rightarrow 0} u^{\prime}(c)=\infty$. We assume that each bank has a unitary mass of depositors.

The uncertainty about the preference shocks for the second group of agents is resolved in period 1 when each depositor privately learns his or her type. We assume that each bank $i$ faces liquidity uncertainty in the sense that the fraction $\omega^{i}$ of early consumers is stochastic and can have two possible realizations, namely $\omega_{H}$ and $\omega_{L}$, with $\omega_{H}>\omega_{L}$. In this way $\omega^{i}$ plays the role of a liquidity shock for bank $i$ which can either be high or low. While individual preference shocks are privately observed by consumers, the liquidity shock of each bank is publicly observed by everyone.

We assume that in normal times the two banks have opposite shocks. More specifically shocks are asymmetric with probability $p>1 / 2$. With some (possibly) small probability $1-p$, however, both banks are hit by the high liquidity shock. Formally, there are three 
possible states of the world $s \in \mathcal{S}=\{H L, L H, H\}$. In states $H L$ and $L H$ banks are hit by different shocks, while in state $H$ they both have high liquidity needs. Table 1 summarizes the probability distribution of the liquidity shocks.

Table 1: Banks' liquidity shocks

\begin{tabular}{cccc}
\hline State & Bank A & Bank B & Probability \\
\hline$H L$ & $\omega_{H}$ & $\omega_{L}$ & $p / 2$ \\
$L H$ & $\omega_{L}$ & $\omega_{H}$ & $p / 2$ \\
$H$ & $\omega_{H}$ & $\omega_{H}$ & $1-p$ \\
\hline
\end{tabular}

The structure of the shocks captures the existence of both diversifiable and undiversifiable liquidity risk, and $p$ measures to what extent the risk is diversifiable. In fact, in states $H L$ and $L H$, the average fraction of early consumers in the two banks is constant and equal to $\omega_{H L}=\left(\omega_{H}+\omega_{L}\right) / 2$. The risk faced by each bank is therefore diversifiable in this case, and this happens with probability $p$. In state $H$, however, the fraction of early consumers is $\omega_{H}>\omega_{H L}$ in both banks, so that the occurrence of this state represents undiversifiable uncertainty and this happens with probability $1-p .^{8}$

Agents cannot trade directly with one another, but the banking sector makes up for the missing markets. In particular, the activity of each bank develops as follows. At $t=0$ each bank collects the initial endowment of its depositors and an amount $e \geq 0$ of resources from investors. The amount $e$ will henceforth be referred to as bank capital. The bank invests an amount $y$ in the short asset and an amount $1+e-y$ in the long asset; in period 1 , after the state $s$ is publicly observed, the consumer reveals his preference shock to the bank and receives the consumption vector $\left(c_{1}^{s}, 0\right)$ if he is an early consumer and the consumption vector $\left(0, c_{2}^{s}\right)$ if he is a late consumer. Similarly, after the state $s$ has been observed, investors receive the consumption vector $\left(d_{1}^{s}, d_{2}^{s}\right) \geq 0 .{ }^{9}$ Therefore, a risk sharing

\footnotetext{
${ }^{8}$ To put it differently, undiversifiable liquidity risk can be measured by the volatility of the average fraction of early consumers in the two banks. This fraction is $\omega_{H L}$ with probability $p$ and $\omega_{H}$ with probability $1-p$. The variance of this binary random variable is $p(1-p)\left(\omega_{H}-\omega_{H L}\right)^{2}$, which is maximum for $p=1 / 2$ and decreases monotonically in $p$.

${ }^{9}$ Agents are in a symmetric position ex-ante, and we assume that they are treated equally, that is, risk averse agents are all given the same contingent consumption plan, summarized by $\left\{c_{t}^{s}\right\}_{s \in \mathcal{S} ; t=1,2}$ and, similarly, risk neutral agents are all given the same contingent consumption plan $\left\{d_{t}^{s}\right\}_{s \in \mathcal{S} ; t=1,2}$.
} 
contract, also called an allocation, offered by the bank is fully described by an array

$$
\left\{y, e,\left\{c_{t}^{s}, d_{t}^{s}\right\}_{s \in \mathcal{S} ; t=1,2}\right\}
$$

In what follows we are interested in studying how the level of bank capital is affected by the existence of undiversifiable liquidity risk. As it is standard in this class of models (e.g., Allen and Gale [5]), we proceed by first characterizing optimal risk sharing and then briefly describing its decentralization by means of interbank deposits.

\section{Optimal Risk Sharing}

Following Gale [20], we consider optimal risk sharing in a situation where investors are perfectly competitive and their supply of capital is perfectly elastic. Hence, investors are maintained at their reservation utility. We look for the allocation chosen by a social planner that maximizes the ex-ante expected utilities of depositors and guarantees investors the same utility, in expectation, that they could obtain by consuming their endowment at $t=0$. Notice that the overall fraction of early consumers is the same in states $H L$ and $L H$, and it is therefore optimal to move resources from one bank to the other and make agents' consumption plans constant in these states, that is $c_{t}^{H L}=c_{t}^{L H}$ for $t=1,2$. Similarly we have $d_{t}^{H L}=d_{t}^{L H}$ for $t=1,2$. To ease notation we can simply refer to $c_{t}^{H L}$ and $d_{t}^{H L}$ as the common consumption and payout streams in states $H L$ and $L H$.

An allocation can be described by an array $\left\{y, e,\left\{c_{t}^{s}, d_{t}^{s}\right\}_{s=H L, H ; t=1,2}\right\}$, and it is said to be feasible if for $s=H L, H$ and $t=1,2$, we have $e \geq 0, d_{t}^{s} \geq 0$, and

$$
\begin{aligned}
\omega_{s} c_{1}^{s}+d_{1}^{s} & \leq y, \\
\left(1-\omega_{s}\right) c_{2}^{s}+d_{2}^{s} & \leq(1+e-y) R+y-\omega_{s} c_{1}^{s}-d_{1}^{s}, \\
p\left(\rho_{1} d_{1}^{H L}+d_{2}^{H L}\right)+(1-p)\left(\rho_{1} d_{1}^{H}+d_{2}^{H}\right) & \geq \rho_{0} e .
\end{aligned}
$$

The first two constraints guarantee that there are enough resources at $t=1$ and $t=2$, respectively, to deliver the planned amount of consumption in each state $s$. Whenever $y-\omega_{s} c_{1}^{s}-d_{1}^{s}>0$ we say that there is positive rollover in state $s$, that is, some resources are stored through the liquid asset between $t=1$ and $t=2$. In this case the ex-post social value of liquidity is clearly the lowest possible as it exceeds overall needs. The third 
constraint guarantees that investors get at least their reservation utility in expectation. ${ }^{10}$ To characterize optimal risk sharing, we can think of a planner choosing a feasible allocation to maximize

$$
p\left(\omega_{H L} u\left(c_{1}^{H L}\right)+\left(1-\omega_{H L}\right) u\left(c_{2}^{H L}\right)\right)+(1-p)\left(\omega_{H} u\left(c_{1}^{H}\right)+\left(1-\omega_{H}\right) u\left(c_{2}^{H}\right)\right) .
$$

In state $H$ each bank's promised consumption plans must be satisfied with the resources available within the bank. In fact, in state $H$, both banks need an amount of liquidity equal to $\omega_{H} c_{1}^{H}+d_{1}^{H}$ and from (1) we see that the available amount of the short asset within each bank is enough to cover the liquidity need (i.e., $y \geq \omega_{H} c_{1}^{H}+d_{1}^{H}$ ). Things are different in states $H L$ and $L H$ : in this case in order to implement the first best, the planner has to move resources between the two banks. For example, with no rollover in states $H L$ and $L H$, the amount of liquid resources available at $t=1 \mathrm{in}$ both banks is $\omega_{H L} c_{1}^{H L}+d_{1}^{H L}$. However, one bank has a fraction $\omega_{H}$ of early consumers so that its liquidity need is $\omega_{H} c_{1}^{H L}+d_{1}^{H L}$, which results in a shortage of liquidity equal to $\left(\omega_{H}-\omega_{H L}\right) c_{1}^{H L}$. At the same time, the other bank has a fraction $\omega_{L}$ of early consumers so that its liquidity need is only $\omega_{L} c_{1}^{H L}+d_{1}^{H L}$, which results in an excess amount of liquidity equal to $\left(\omega_{H L}-\omega_{L}\right) c_{1}^{H L}$. Given that

$$
\left(\omega_{H}-\omega_{H L}\right)=\left(\omega_{H L}-\omega_{L}\right)=\left(\omega_{H}-\omega_{L}\right) / 2
$$

the liquidity shortage in one bank can be covered by the excess liquidity of the other bank at $t=1$. At $t=2$, interbank flows go in the opposite direction in states $H L$ and $L H$ to cover the shortage of resources at one bank with the excess of the consumption good at the other, while in state $H$ each bank has exactly the resources it needs. ${ }^{11}$

Consider now a decentralized economy in which each bank directly offers a risk-sharing contract to its depositors and investors. A standard result in this literature is that if banks are perfectly competitive on the deposit market, and therefore maximize the ex-ante utility of their depositors, the decentralized economy achieves optimal risk sharing. ${ }^{12}$ To show

\footnotetext{
${ }^{10}$ We are not explicitly considering the incentive contraints $c_{1}^{s} \leq c_{2}^{s}$ that prevent late consumers from pretending to be early consumers since the solution to the unrestricted problem automatically satifies such incentives constraints (see Proposition 1).

${ }^{11}$ Similar interbank flows take place in the case of positive rollover in states $H L$ and $L H$.

${ }^{12}$ The economy consists of two banks together with their investor and depositor bases. We take these elements as primitives and look at whether banks are able to exploit the available risk-sharing opportunities provided by the interbank market when they act competitively. Competition among banks is however not modelled directly: it may occur between the two banks explicitly considered, but it may also come from potential entrants as well as other banks.
} 
this result, we have to check whether banks can find some arrangement to make the firstbest allocation feasible for each bank individually, and the interbank deposits offer this possibility.

Assume that each bank offers the first-best allocation to its depositors and investors, and deposits the amount $\omega_{H}-\omega_{H L}$ with the other bank, under the same conditions applied to individual depositors. This means that when the fraction of early consumers in bank $i$ is $\omega_{H}$, bank $i$ will behave as an early consumer and withdraw its interbank deposit at $t=1$. In this case the bank obtains nothing at $t=2$, whereas at $t=1$ it gets $\left(\omega_{H}-\omega_{H L}\right) c_{1}^{H L}$ if the fraction of early consumers in the other bank is $\omega_{L}$, and $\left(\omega_{H}-\omega_{H L}\right) c_{1}^{H}$ otherwise. If the fraction of early consumers in bank $i$ is $\omega_{L}$, bank $i$ will behave as a late consumer by holding its interbank deposit until $t=2$, when it will finally withdraw it. In this case the bank obtains zero at $t=1$ and $\left(\omega_{H}-\omega_{H L}\right) c_{2}^{H L}$ at $t=2$, as the fraction of early consumers in the other bank is $\omega_{H}$. It is straightforward to check that with the use of interbank deposits, the first-best allocation is feasible and will therefore be offered in a perfectly competitive deposit market.

\section{First-Best Allocation}

In this section we characterize the first-best allocation and we study the role of both bank capital and interbank deposits in achieving optimal risk sharing. Interbank deposits are useful when bank liquidity needs are asymmetric, that is in states $H L$ and $L H$. In fact, because the average liquidity need is constant in these states, interbank deposits allow the channelling of the excess liquidity of one bank toward the other, which instead has a liquidity shortage. In this way depositors can be guaranteed a constant level of consumption in states $H L$ and $L H$. However, interbank deposits are useless when both banks have high liquidity needs, i.e., in state $H$, and in this case depositors cannot obtain the same level of consumption as in states $H L$ and $L H$. It is the existence of undiversifiable liquidity uncertainty that creates a scope for bank capital in this model.

By raising costly bank capital, part of the undiversifiable risk can be transferred to riskneutral investors, therefore offering to depositors some insurance against the occurrence of state $H$, and the corresponding shock on consumption. The following result formalizes this intuition and summarizes the basic characteristics of the first-best allocation. 
Proposition 1 Assume $p<1$ and consider the first-best allocation. We have

$$
c_{1}^{H}<c_{1}^{H L} \leq c_{2}^{H L}<c_{2}^{H} .
$$

Moreover, $d_{1}^{H L} \geq d_{1}^{H}=0 ; d_{2}^{H} \geq d_{2}^{H L}=0$; and positive rollover either occurs in states $H L$ and $L H$, in which case $c_{1}^{H L}=c_{2}^{H L}$, or it never occurs, in which case $c_{1}^{H L}<c_{2}^{H L}$.

This result is proved in Appendix A and shows that banks do not offer full insurance to risk-averse depositors. In particular, first-period (second-period) consumption tends to decrease (increase) with the overall fraction of early consumers. Banks can however transfer part of the undiversifiable uncertainty to the risk-neutral investors by collecting part of their resources at $t=0$, in the form of bank capital, in exchange for a contingent payout at $t=1,2$. The optimal way of arranging this form of risk sharing is to avoid any payout to investors when the marginal utility of depositors is high, that is, in state $H$ at $t=1$, and in states $H L$ and $L H$ at $t=2$. The reason why banks choose not to raise enough capital to fully insure their depositors is because bank capital is costly. Notice that when depositors are fully insured (i.e., $c_{t}^{H}=c_{t}^{H L}$, for $t=1,2$ ) the marginal value of insurance is zero but the marginal cost of capital is positive, as investors require a return $\rho_{0}>R$ to postpone consumption to $t=2$, and a return $\rho_{0} / \rho_{1}>1$ to postpone consumption to $t=1$. In any case, the cost of capital is higher than the returns of available investment opportunities (see Allen and Gale [6]), and this makes room for only a limited use of bank capital. ${ }^{13}$

\subsection{Bank Capital}

The optimal amount of bank capital clearly depends on how much liquidity risk is diversifiable, here captured by the parameter $p$. Let us use the notation $e(p)$ to make this relationship explicit. Intuitively, a larger $p$ means that interbank deposits can be used more often to smooth liquidity shocks and, as a consequence, the incentive to raise bank capital should be smaller. This intuition is corroborated by the fact that bank capital is zero when $p=1 .{ }^{14}$ Indeed, with no aggregate uncertainty interbank deposits are sufficient

\footnotetext{
${ }^{13}$ The first-best level of capital is zero if $\rho_{0}$ is much larger than $\rho_{1}$. In this case bank capital becomes too costly to be used for risk-sharing purposes. In what follows we exclude this trivial possibility by assuming that $\rho_{0}$ and $\rho_{1}$ are compatible with the use of a positive amount of capital.

${ }^{14}$ To see this just notice that with $p=1$ the first-order conditions indentifying optimal risk sharing imply $e\left(R-\rho_{0}\right) u^{\prime}\left(c_{2}^{M}\right)=0$. Because $\rho_{0}>R$ and $u^{\prime}\left(c_{2}^{M}\right)>0$, it follows that $e=0$.
} 
to smooth away idiosyncratic liquidity shocks, and there is no need to raise costly bank capital. The following result now immediately follows from a simple continuity argument.

Proposition 2 If $p^{\prime}>p$ and $p^{\prime}$ is sufficiently close to one, whenever $e(p)>0$ we also have $e\left(p^{\prime}\right)<e(p)$.

In other words, whenever bank capital is used for risk-sharing purposes, its level eventually decreases as the nature of the liquidity shocks becomes predominantly idiosyncratic. Figure 1 shows a numerical example in which bank capital is decreasing for all values of $p \geq 1 / 2$, not only for sufficiently high values. ${ }^{15}$

\section{[FIGURE 1]}

From panel (a) we can see that bank capital over total assets is indeed decreasing for all values of $p \geq 1 / 2$. Panel (b) shows that investors receive a payout at $t=2$ in state $H$ for any $p \in(1 / 2,1)$, while a payout at $t=1$ in states $H L$ and $L H$ is only realized when $p$ is below approximately 0.68. However, the negative relationship between the level of bank capital and $p$ is not a general property of the model. Figure 2 shows a numerical example where bank capital can indeed increase in $p$ over some range. ${ }^{16}$

\section{[FIGURE 2]}

Panel (a) in Figure 2 shows that bank capital is slightly increasing until about $p=0.65$ and decreasing thereafter. To understand why this can happen consider that a reduction of the undiversifiable liquidity uncertainty (i.e., an increase in $p$ ) can induce banks to reduce their investment in the liquid asset, and in some cases this can lead to higher consumption volatility (see also Castiglionesi et al. [11]). The variance of consumption at $t=1,2$ is given by $p(1-p)\left(c_{t}^{H L}-c_{t}^{H}\right)^{2}$, so that for fixed consumption levels, and $p \geq 1 / 2$, an increase in $p$ has a direct effect which tends to reduce volatility. However, there is also an indirect effect on consumption levels which can go in the opposite direction. In fact, when some liquidity is paid out to investors at $t=1$ or rolled over to $t=2$ in states $H L$ and $L H$,

\footnotetext{
${ }^{15}$ The example assumes $R=1.8, \rho_{0}=2, \rho_{1}=1.75, \omega_{H}=0.6, \omega_{L}=0.4$, and depositors have constant relative risk aversion equal to 2 .

${ }^{16}$ This example assumes $R=1.4, \rho_{0}=1.55, \rho_{1}=1.50, \omega_{H}=0.6, \omega_{L}=0.4$, and depositors have constant relative risk aversion equal to 2 .
} 
both first- and second-period consumption levels in these states are not very sensitive to the reduction in liquidity associated with the larger $p .^{17}$

This is what happens in the example of Figure 2 where the sensitivity of consumption levels to the amount of liquid resources is higher in state $H$ than in states $H L$ and $L H$. The consequence is that reduced liquidity tends to reduce early consumption and increase late consumption more in state $H$ than in states $H L$ and $L H$ and, given Proposition 1 , this means that $\left(c_{t}^{H L}-c_{t}^{H}\right)^{2}$ tends to increase, for both $t=1,2$. When $p$ is close to $1 / 2$, and therefore volatility is most sensitive to variation of $\left(c_{t}^{H L}-c_{t}^{H}\right)^{2}$, this effect can be strong enough to eventually increase the standard deviation of consumption. Banks may therefore find it optimal to increase their capital levels to moderate the tendency toward increased consumption volatility associated with reduced liquidity.

Panel (b) in Figure 2 indeed shows that the liquidity ratio, defined as $y /(1+e)$, is always decreasing in $p$, both when bank capital is optimally set to the levels shown in panel (a), and when it is set to zero. Panels (c) and (d) display the first- and, respectively, secondperiod consumption volatility, both with and without bank capital, and show the tendency toward increased consumption volatility when $p$ increases. Notice that in the absence of bank capital, consumption volatilities are higher. This confirms that bank capital is used to offer depositors partial insurance against the occurrence of state $H$. Notice also that, in the absence of bank capital, the consumption volatility both in the first and in the second period increases with $p$, for values of $p$ below some threshold. This effect is the result of the reduced liquidity ratio documented in panel (b), and induces banks to increase their capital ratio.

Despite the possibility of $e(p)$ being increasing over some range for $p$ close to its lower bound, Proposition 2 clarifies that eventually the optimal level of bank capital will be decreasing when $p$ varies in some range close to its upper bound. We argue that in developed economies banks can rely extensively on interbank deposits, as well as on ex-post markets such as the Repo and Fed-Funds markets, to manage their liquidity risk. Therefore it seems conceivable that for much of the time banks are likely to find suitable counterparties to trade with. Only occasionally they might still find it difficult to obtain liquidity from the market. In terms of our model this means that banks in developed economies are

\footnotetext{
${ }^{17}$ In this case a bank can easily compensate the reduced liquidity by properly adjusting the amount of rollover or the first-period payout, which both effectively represent a kind of liquidity buffer in states $H L$ and $L H$.
} 
better characterized as facing low levels of undiversifiable liquidity risk, i.e., a relatively high $p$. Hence, to the extent that the liquidity risk-sharing function of capital is relevant, we expect to find empirically a negative relationship between bank capital and proxies of $p$ (or, equivalently, a positive relationship between capital and proxies of $1-p$ ).

\section{Empirical Analysis}

\section{$5.1 \quad$ Data}

Given the theoretical framework provided in the previous section, we hypothesize that, if the liquidity risk-sharing function of bank capital is relevant, we should observe a negative relationship between bank capital and the probability $p$ of being able to use the interbank market. A critical step in the empirical analysis is to find a proxy for the parameter $p$, which represents the coinsurance possibilities offered by the interbank market.

The possibility to obtain coinsurance certainly reflects general factors, such as the development of the overall interbank network. However, banks have different abilities to access the interbank market which are due to various characteristics, like the business model, the portfolio of loans, the number of connections with other banks, the profitability, the risk profile, the past repayment behavior and even the characteristics of connected banks (see, for example, Cocco et al. [12]). These bank-specific characteristics clearly vary in the cross section but they can also vary over time. Therefore any empirical measure of diversifiable liquidity risk $p$ is expected to change over time for a given bank and in the cross section.

Our approach to measuring banks' coinsurance possibilities consists of looking at their interbank market activity. More precisely, we take the sum of lending (interbank assets) and borrowing (interbank liabilities) positions on the interbank market as a measure of interbank activity. As interbank assets are deposits held at other banks that can be used to repond to withdrawals, together with interbank borrowing they provide a proxy of co-insurance opportunities offered by the interbank market.We postulate that more interbank transactions in a certain period reflect a higher probability of making use of the interbank market in the future to diversify liquidity risk. A bank (or a banking system) with a large interbank activity is more likely to manage its liquidity needs in the interbank market, [make use of the interbank market, 
i.e., it faces a higher $p$, than a bank (or a banking system) with a low interbank activity. [So, we take the measure of interbank activity as our proxy of $p$.]

Banks' transactions on the interbank market typically take place over the counter and detailed data are not publicly available. However, information on banks' interbank activity can be obtained from the quarterly data provided by the Federal Deposit Insurance Corporation (FDIC) Statistics on Depository Institutions (SDI). The SDI repository includes all FDIC-insured institutions and it contains detailed on- and off-balance-sheet information for all banks. ${ }^{18}$

We build a quarterly panel dataset spanning from the first quarter of 1995 to the second quarter of 2007. The choice to concentrate on the pre-crisis period is motivated by the fact that reported bank capital during the crisis might be unreliable (for example, banks close to the regulatory capital constraints faced regulatory pressure to increase the level of equity). Moreover, the interbank market was unable to work smoothly during the crisis. ${ }^{19}$ Nevertheless, as a robustness check, we also perform our analysis in an extended sample which includes the crisis period. After excluding banks that do not report their interbank market activity or some other relevant variables, we end up with an unbalanced panel of 5,871 banks. $^{20}$

For the banks in our sample we obtain information on several balance-sheet items as well as on their activity in three different interbank markets: (i) Unsecured interbank lending and borrowing; (ii) Repos and Reverse Repos with maturities longer than one day; and (iii) Overnight (Reverse) Repos and Federal Funds markets. The positions in (ii) and (iii) are however reported jointly by banks until 2002, so we can only distinguish a bank's activity in (i) from its joint activity in (ii) and (iii). We perform our analysis considering the activity on the unsecured interbank market (i) as our main proxy for liquidity risk diversifiability.

\footnotetext{
${ }^{18}$ The FDIC repository database is available at http://www2.fdic.gov/sdi/. The SDI dataset is based on the quarterly Federal Financial Institutions Examination Council (FFIEC) Reports of Condition and Income (briefly, "Call Reports"). The SDI data that we consider are analogous to the Call Reports for banks with domestic and foreign offices (FFIEC031) and for banks with domestic offices (FFIEC041).

${ }^{19}$ Similarly, we start from 1995 to avoid the effects of the S\&L crisis, which lasted until 1994 and in which more than 1,600 banks closed or received financial assistance from the FDIC.

${ }^{20}$ The SDI repository database contains information on 14,771 banks from 1995 to 2012. The majority of the banks have total assets below $\$ 300$ million. From 2001 these banks are not required to report information on unsecured interbank lending and borrowing activity. This reduces the number of banks to 7,143 . Considering missing values of some of the other control variables the sample shrinks to 6,556 banks. Excluding the crisis period 2007Q3-2012Q4 we end up with 5,871 banks.
} 
We also control for the overall activity on the Repo and Fed Funds markets (ii) and (iii) as they certainly represent an important source of liquidity for banks. The Repo and Fed Funds markets are however actively used also by non-banking institutions, while our analysis focuses on the banking system. We therefore prefer to concentrate on the activity on the interbank market (i), which is simply referred to as interbank activity (Interbank) in what follows, and is measured by the sum of balances due from depository institutions (i.e., all the short-term credits banks provide to other banks) and deposits from depository institutions (i.e., all short-term resources banks borrow from other banks) normalized by total assets. As for capital (Capital), we adopt a broad definition consisting of the book value of total equity, including both common and preferred stock, normalized by total assets. In this way we intend to include any source of funding with a long maturity and no collateral, whose remuneration is flexible enough to be potentially used to absorb undiversifiable liquidity shocks. ${ }^{21}$

To test the negative relationship between a bank's activity in the interbank market and the level of its capital, we include various balance-sheet variables to control for factors that might induce a spurious correlation.

The first control that we consider is the activity of banks on the Repo and Fed Fund markets (Fed Funds Repos), measured by the sum of corresponding assets and liabilities, normalized by total assets. These markets clearly represent a, potentially important, source of liquidity which can have an effect on the level of bank capital. ${ }^{22}$

The second set of control variables contains measures related to banks' liquidity holdings. The first variable is cash and government securities (Liquidity), while the second is the amount of money deposited with the FED (Deposits Fed). We also control for the amount of retail deposits (Deposits) a bank has, and the amount of its outstanding loans (Loans). The riskiness of a bank is captured through its loan loss provisions (LLP). All of these variables are normalized by total assets. Furthermore, we include the return on

\footnotetext{
${ }^{21}$ In this Section, we quickly describe the main variables used in the analysis. Table B1 in Appendix B contains a detailed description of all the variables and their reference codes in the SDI and Call Reports databases.

${ }^{22}$ After 2002 it is possible to distinguish the activity on the Repo and Fed Fund markets. Considering only the sample after 2002 we have therefore been able to repeat our analysis using the activity in these markets as two separate control variables. The qualitative results remain unchanged. For the entire sample period it is also possible to consider Repo and Fed Funds transactions together with the unsecured interbank transactions as a broader measure of interbank activity. Again, our qualitative results also hold true with this alternative measure. These results are unreported but are available upon request.
} 
assets $(R O A)$ to reflect the impact of profitability, and we finally control for bank size (Size), as measured by total assets. Extreme observations are winsorized at the top and bottom $2.5 \%$.

Table 2 provides descriptive statistics for our main variable, and shows that the sample exhibits considerable heterogeneity. On average the variable Capital is 10\%, and it standard deviation is $5.2 \%$. The same applies to our measure of interbank activity (Interbank), which is $2.5 \%$ and has a median of $1.5 . \%$. The dispersion is rather significant: the variable Interbank ranges from $0.01 \%$ at the 5 th percentile to $8.5 \%$ at the 95 th percentile with a standard deviation of $3.9 \%$. Finally, notice that the sample includes large, medium, and small banks, with an average size of $\$ 2,572$ million, and a median size of $\$ 342$ million.

\section{[TABLE 2]}

\subsection{Aggregate Evidence}

We first show that the negative relationship between bank capital and interbank activity holds in aggregate terms for the U.S. banking system. Using the SDI dataset, we obtain yearly aggregate statistics on the interbank activity of U.S. banks as well as their capitalization. The aggregate bank capital ratio in a certain year is defined as the sum of the book value of equity, including both common and preferred stock, over the sum of the total assets of all the banks that appear in the SDI dataset in that year. Similarly, in any given year the aggregate measure of interbank activity is given by the sum of the balances due from depository institutions and the deposits from depository institutions of all the banks in the SDI dataset, divided by the sum of banks' total assets. Figure 3 shows how aggregate measures of bank capital ratios and interbank activity have evolved between 1995 and 2006 in the U.S. banking system.

[FIGURE 3]

The aggregate bank capital ratio has been increasing over time while the overall unsecured interbank activity has been decreasing. ${ }^{23}$ The correlation between the two variables is -0.83 and is significant at a level of $1.27 \%$. This is a first indication that at least part of

\footnotetext{
${ }^{23}$ The aggregate measure for the Repo and Fed Funds assets and liabilities shows no trend in the period considered.
} 
the increase in bank capital ratios might be due to the reduced coinsurance opportunities offered by interbank markets.

An alternative way to look at aggregate trends is to measure how similar the liquidity shocks on deposits across banks are. These shocks are indeed of particular importance in practice, as well as in our theoretical model, and to the extent that they are similar across banks, they represent the undiversifiable liquidity risk $(1-p)$. To assess the existence and the relevance of a common source of variation in deposits, we perform a principal component analysis.

We consider seven non overlapping sub-periods of eight quarters between 1995Q1 and 2008Q4. In each sub-period we consider banks with data available on deposits for all of the eight quarters. We then extract the first principal component (FPC) of deposits, which represents the factor that best accounts for the existence of a common source of variation across banks. We therefore look at the percentage of the overall variability of deposits explained by the FPC, which we call the "commonality of deposits". The larger the fraction of the total deposits variability explained by the FPC, the larger the influence of common and undiversifiable shocks. Table 3 reports the results.

\section{[TABLE 3]}

The FPC explains an increasing fraction of the overall variability of deposits between 1995 and 2008 (the only exception being the 2003-2004 period). The commonality of deposits increases from $39.50 \%$ in the first sub-period, up to $43.71 \%$ in the last. For each sub-period, Table 3 also displays the aggregate banking capital ratios which have been increasing over time. The commonality of deposits is therefore positively related with bank capital and this is consistent with our theoretical model. In fact, the commonality of deposits is a measure of undiversifiable liquidity risk, which is captured by the probability $1-p$ in the model. Hence, the negative relationship between bank capital and $p$ is clearly equivalent to a positive relationship between bank capital and $1-p$. The correlation between the commonality of deposits and bank capital is 0.86 and is statistically different from zero at a level of $1.38 \%$. Table 3 also reports the interbank activity (i.e., our measure of diversifiable liquidity risk captured by the parameter $p$ ) that has been decreasing over time. The data therefore also support the existence of a negative relationship between our proxy for diversifiable liquidity risk and $1-p$. In particular, the correlation between 
the commonality of deposits and interbank activity is -0.76 and is significant at a level of $3.5 \% .^{24}$

We do not attempt to directly explain the documented downward trend in diversifiable liquidity risk and the upward trend in the commonality of deposits. Indeed, our model takes the parameter $p$ as exogenous. However, we notice that empirically these trends are consistent with recent evidence of banks having become more similar on the asset side. For example, Acharya and Yorulmazer (2007) argue that banks' investment behavior became more correlated over time to maximize the government subsidy per invested unit of capital. Nijskens and Wagner (2011) find that the use of Credit Default Swaps and Collateralized Loan Obligations led to a permanent increase in bank risk, measured by banks' share price beta. That is, banks using Credit Risk Transfers (CRT) have become more subject to systematic shocks over time. The similarity induced by the CRT instruments is likely to reduce the scope of liquidity coinsurance among the banks that rely on CRTs. Moreover, it is possible to argue that the increased correlation among banks using the CRTs is likely to have indirect effects on other banks. Banks that do not rely on CRTs would find less heterogenous counterparties to coinsure their liquidity risk, diminishing the possibilities for the former to borrow from (lend to) the latter in the interbank market.

In the next section we turn to the bank-level evidence by performing a regression analysis. In this case we only look at banks' unsecured interbank activity, as measured by the variable Interbank, as a proxy for the diversifiable liquidity risk (i.e., the parameter $p$ ) at the bank level. A proxy of undiversifiable liquidity risk (i.e., a proxy of $1-p$ ) at the bank level based on correlations of deposits (or on a principal component analysis) would require some aggregation of data over time, and would therefore entail a loss of information.

\subsection{Regression Results}

Panel-regression analysis To test for the existence of a negative relationship between bank capital and our measure of diversifiable liquidity risk at the bank level, we first use a panel-regression approach to estimate their conditional correlation. ${ }^{25}$

\footnotetext{
${ }^{24}$ In Table 3 we also indicate for each sub-period the number of banks in our sample that report the information we need for the analysis. As of 2001, many items, including the balances due from depository institutions and the deposits from depository institutions, are no longer reported by banks with total assets below $\$ 300$ million. This explains the large drop in the number of banks after 2000 .

${ }^{25}$ The unconditional correlations of all the variables used in the main regressions are reported in Table B2 in Appendix B.
} 
In the basic specification, we perform the following panel regression:

$$
\text { Capital }_{i, t}=\alpha+\beta \text { Interbank } k_{i, t}+\gamma \mathbf{X}_{i, t}+\varepsilon_{i, t},
$$

where Capital $_{i, t}$ is the capital ratio of bank $i$ at time $t$, Interbank $k_{i, t}$ is our proxy for the diversifiable liquidity risk of bank $i$ at time $t$, the vector $\mathbf{X}_{i, t}$ contains the control variables, and $\varepsilon_{i, t}$ is an error term. Among the controls we also include bank fixed effects and year dummies to account for unobserved heterogeneity at the bank level and across years that may be correlated with the explanatory variables. We also correct for seasonality by using quarterly dummies. Standard errors are clustered at the bank level to account for heteroscedasticity and serial correlation of errors (see Petersen [27]). Table 4 displays the results.

\section{[TABLE 4]}

Column 1 in Table 4 reports the regression of bank capital on interbank activity, bank fixed effects, and time dummies, with the exclusion of the other control variables. It shows that there is a negative relation between the two variables of interest as predicted by the model. The coefficient is -0.018 and it is statistically significant at the $1.4 \%$ level. If we perform a purely univariate analysis, by repeating a similar regression without fixed effect and time dummies, the result is qualitatively similar: the coefficient is -0.021 and it is statistically significant at the $1 \%$ level.

The result of the panel estimation of equation (5), with all controls included, is reported in Column 2 of Table 4. It confirms that our proxy for diversifiable liquidity risk is negatively related to bank capital after controlling for other bank factors (like risk, liquidity holdings, size, and profitability). The coefficient of the variable Interbank is -0.062 , and is significant at the $1 \%$ level. The economic significance of these estimates also seems relevant. For example, the standard deviation of interbank activity within banks (i.e., in the time-series) is $1.71 \%$ in our sample. This means that one within-banks standard deviation increase in interbank activity [an increase of interbank activity of one within-banks standard deviation] is associated with a reduction of $0.11 \%$ in bank capital, which represents $1.1 \%$ of its mean and $1.2 \%$ of its median. Finally, among the control variables, the variable Fed Funds Repos, which with some caveats can be considered an alternative measure of diversifiable liquidity risk, is also negatively related to Capital at the $1 \%$ significance level. 
Cross-sectional analysis The estimation of regression (5) employs bank fixed effects. It therefore uses the time series variation within banks, but fails to exploit cross-sectional differences among banks. However, at any point in time, banks are likely to vary in the cross section in terms of the diversifiability of their liquidity risk, that is, in terms of the particular value of $p$ they face. According to our argument, this implies that they should hold different levels of capital. Table 5 reports some cross-sectional estimates of equation (5), where $t$ is held constant and no fixed effects are included.

\section{[TABLE 5]}

Column 1 refers to the fourth quarter of 1995, Column 2 to the first quarter of 2000 and Column 3 to the first quarter of 2006. All of the three cross-sectional regressions in Table 5 produce a negative and significant coefficient for the variable Interbank.

The economic significance of these estimates is also relevant. As an example, consider the regression in Column 2. The standard deviation of interbank activity in this cross section is $2.67 \%$, so that a one-standard deviation increase in the amount of interbank activity is associated with a reduction of $0.17 \%$ in bank capital, which represents $1.78 \%$ of the cross-sectional mean value. ${ }^{26}$ Similar results also hold for the variable Fed Funds Repos.

To complete the analysis, we also run cross-sectional regressions for all of the quarters in our sample period. Results are not reported here, but in the period between 1995Q1 and $2007 \mathrm{Q} 2$, the coefficient of the variable Interbank is negative and significant at least at the $10 \%$ level in 40 quarters out of 50 (in 20 quarters it shows a significance level of 1\%). This confirms that banks that are more exposed to undiversifiable liquidity shocks than others, tend to hold higher levels of capital.

\subsection{Robustness}

In this section we perform various robustness checks to see whether the empirical results we obtain with the basic specification (5) also hold in different sub-samples of particular interest.

\footnotetext{
${ }^{26}$ Similarly, the standard deviations of interbank activity in 1995Q4 and 2006Q1 are 2.94\% and, respectively, 3.16\%. A one-standard deviation increase in interbank activity is therefore associated with a reduction in bank capital of $0.21 \%$ and, respectively, $0.22 \%$, in the two cross sections, which represent $2.17 \%$ and $2.22 \%$ of the corresponding cross-sectional means. Finally, notice that the overall between-banks standard deviation of interbank activity in the sample is $2.37 \%$.
} 
Pre-crisis vs. crisis period. Our theoretical model describes a general mechanism without delivering different predictions for crisis and non-crisis periods. However, it is likely that during a financial crisis the relationship between bank capital and interbank activity will be affected by factors not captured in our theoretical analysis. Starting from the summer of 2007, interbank markets have been extremely stressed and governments have been forced to intervene providing liquidity assistance and closely monitoring banks. For this reason we have focused our main analysis on a period ending at the second quarter of 2007. Table 6 reports evidence on the relationship between bank capital and interbank market activity for an extended sample (1995Q1-2012Q4), and for the crisis period (2007Q3-2012Q4) in isolation.

\section{[TABLE 6]}

Table 6 shows that the predicted negative relationship is present both in the extended sample (Column 1) and in the crisis period (Column 2). The coefficient of the variable Interbank is negative and significant in both cases. Notice that it has a larger magnitude in the crisis period, suggesting that bank capital and interbank markets might have been even closer substitutes during the crisis. ${ }^{27}$

Net Lender vs. Net Borrower banks. A possible concern might be that some banks act mainly as borrowers (or lenders) in the interbank market, and the negative relationship between capital and interbank activity could be driven by this specialization of banks. To check the robustness of our results we therefore split the sample between net lender and net borrower banks. Table 7 displays the results.

\section{[TABLE 7]}

Column 1 shows the results for the net lender banks, and Column 2 reports the regression for the net borrower banks. While the magnitude is much larger for net borrower banks, both regressions show a negative coefficient of the Interbank variable which is significant at the $1 \%$ level.

Bank size. Another concern is due to the large size dispersion of U.S. banks. This implies that controlling for bank fixed effects and size in a panel regression may not be enough. For this reason we break down the sample of banks into different size categories. In

\footnotetext{
${ }^{27} \mathrm{~A}$ similar result obtains if we alternatively take the third quarter of 2008 as the beginning of the crisis period.
} 
particular, we look separately at banks with a total asset value smaller than $\$ 300$ million, between $\$ 300$ million and $\$ 1$ billion, between $\$ 1$ billion and $\$ 50$ billion, and over $\$ 50$ billion. Results are reported in Table 8.

\section{[TABLE 8]}

Columns 1, 2, 3, and 4 report the regressions for each of the four size categories (from smallest to largest). They show that the relationship between capital and interbank activity is negative and significant in each of the different size categories.

Further robustness checks. Even if in our theoretical model regulation played no role, in practice banks do face capital regulation. It is conceivable that the ability of a bank to use its capital to deal with liquidity uncertainty is affected by how close the capital is to the regulatory capital requirement. Splitting the sample between banks that hold a total regulatory capital ratio above $10 \%$ and banks that hold a total regulatory capital ratio below $10 \%$ does not alter our findings. We perform a further robustness check by using data on non-U.S. commercial banks. In particular, we use Bankscope to collect yearly balance-sheet information for a sample of 863 European and Japanese commercial banks from 2005 to 2010. The data does not allow us to distinguish between unsecured interbank lending and Repos, hence our measure of interbank activity includes both. We find that our main results also hold true in this sample. These two robustness checks are not shown here but are available upon request.

\section{Conclusions}

In this paper we analyzed a model of multiple banks to study how the presence of an interbank market affects the incentives to hold bank capital for liquidity risk-sharing purposes. The model predicts a negative relationship between bank capital and empirical proxies of the coinsurance opportunities offered by the interbank market. We use the SDI quarterly dataset for U.S. commercial banks to empirically validate this theoretical prediction. Overall, our empirical results provide evidence of the risk-sharing role of bank capital. Notice that theories that view bank capital as an indicator of solvency would rather predict a positive relationship between bank capital and interbank market activity.

This implies that our findings should be given more attention in the policy debate. Indeed, the current debate on the regulation of bank capital mainly emphasizes its incentive 
function (see, among others, Admati et al. [1]). This is clearly an important role of bank capital, but our results suggest that its function in dealing with the liquidity risk is also relevant, and has been essentially overlooked so far. Any intervention to regulate bank capital is likely to affect the functioning of the markets in which banks coinsure their liquidity risk in a non-trivial way. Future research should try to understand how imposing capital requirements affects banks' behavior on interbank markets and, more generally, their ability to handle liquidity risk.

\section{Appendix A: Proofs}

To simplify the exposition it is useful to determine optimal levels of consumption for assigned values of $y$ and $e$ when the fraction of early consumers is $\omega$ and the stream of dividends paid to investors is $d_{1}, d_{2}$. Formally, given $\left(y, e, d_{1}, d_{2}, \omega\right)$ with $y \in[0,1+e]$, $\omega \in(0,1), e \geq 0, y>d_{1} \geq 0,(1+e-y) R>d_{2} \geq 0$, we consider the value function

$$
\begin{aligned}
V\left(y, e, d_{1}, d_{2}, \omega\right) \equiv & \max _{c_{1}, c_{2}}\left\{\omega u\left(c_{1}\right)+(1-\omega) u\left(c_{2}\right)\right. \\
& \text { s.t. } \left.\omega c_{1}+d_{1} \leq y \text { and }(1-\omega) c_{2}+d_{2} \leq(1+e-y) R+y-\omega c_{1}-d_{1}\right\},
\end{aligned}
$$

and we denote with $C_{t}\left(y, e, d_{1}, d_{2}, \omega\right)$ the corresponding optimal consumption at $t$. Lemmas 1 and 2 below summarize some important properties of the value function and the associated consumption policies.

Lemma 1 The value function $V$ is strictly concave, continuous and differentiable in $\left(y, e, d_{1}, d_{2}\right)$ with

$$
\begin{gathered}
\partial V / \partial y=u^{\prime}\left(C_{1}\right)-R u^{\prime}\left(C_{2}\right) \\
\partial V / \partial e=R u^{\prime}\left(C_{2}\right) \\
\partial V / \partial d_{t}=-u^{\prime}\left(C_{t}\right)
\end{gathered}
$$

The policies $C_{1}$ and $C_{2}$ are given by

$$
\begin{aligned}
& C_{1}=\min \left\{\frac{y-d_{1}}{\omega}, y+(1+e-y) R-d_{1}-d_{2}\right\} \\
& C_{2}=\max \left\{\frac{(1+e-y) R-d_{2}}{1-\omega}, y+(1+e-y) R-d_{1}-d_{2}\right\} .
\end{aligned}
$$


Proof. To show the strict concavity of the value function note that if $c=\left(c_{1}, c_{2}\right)$ and $c^{\prime}=\left(c_{1}^{\prime}, c_{2}^{\prime}\right)$ are optimal with $\xi=\left(y, e, d_{1}, d_{2}, \omega\right)$ and, respectively, $\xi^{\prime}=\left(y^{\prime}, e^{\prime}, d_{1}^{\prime}, d_{2}^{\prime}, \omega\right)$, then given $\alpha \in(0,1), c^{\alpha}=\alpha c+(1-\alpha) c^{\prime}$ is feasible for $\xi^{\alpha}=\alpha \xi+(1-\alpha) \xi^{\prime}$. Now, the strict concavity of $u$ implies that if $\xi \neq \xi^{\prime}$ then also $c \neq c^{\prime}$ and, therefore, the strict concavity of $V$ follows from the strict concavity of $u$. Continuity follows from the theorem of the maximum, and differentiability follows using concavity and a standard perturbation argument to find a differentiable function which bounds $V$ from below. To obtain (7), note that from the envelope theorem

$$
\partial V / \partial y=\lambda+(1-R) \mu
$$

where $\lambda$ and $\mu$ are the Lagrange multipliers on the two constraints. The problem's first order conditions are

$$
\begin{aligned}
& u^{\prime}\left(C_{1}\right)=\lambda+\mu, \\
& u^{\prime}\left(C_{2}\right)=\mu,
\end{aligned}
$$

which substituted in the previous expression give (7). Expressions (8) and (9) are obtained similarly, and considering separately the cases $\lambda>0$ (no rollover) and $\lambda=0$ (rollover), it is possible to derive the optimal consumption policies.

Lemma $2 C_{1} \leq C_{2}$ for all admissible $\left(y, e, d_{1}, d_{2}, \omega\right)$. In particular given

$$
\widehat{y}=\frac{\omega\left(R(1+e)-d_{2}\right)+(1-\omega) d_{1}}{1-\omega+\omega R}
$$

we distinguish two cases:

(i) If $y>\widehat{y}$ there is rollover and we have

$$
\frac{y-d_{1}}{\omega}>C_{1}=C_{2}=y+R(1+e-y)-d_{1}-d_{2}>\frac{(1+e-y) R-d_{2}}{1-\omega},
$$

(ii) If $y \leq \widehat{y}$ there is no rollover and we have

$$
C_{1}=\frac{y-d_{1}}{\omega} \leq y+R(1+e-y)-d_{1}-d_{2} \leq \frac{(1+e-y) R-d_{2}}{1-\omega}=C_{2},
$$

where the inequalities are strict if $y<\widehat{y}$ or otherwise hold as equalities. 
Proof of Lemma 2. The proof follows from inspection of $C_{1}$ and $C_{2}$ in Lemma 1.

Since $C_{1} \leq C_{2}$ late consumers never have an incentive to mimic early consumers. Clearly, the opposite is also true so that, even if consumers have private information on their preference shocks, incentive compatibility is not an issue here.

The first best allocation can now be characterized in terms of the value function defined in (6). In particular, consider the following problem

$$
\max _{\left(y, e, d_{1}^{H L}, d_{2}^{H L}, d_{1}^{H}, d_{2}^{H}\right)} p V\left(y, e, d_{1}^{H L}, d_{2}^{H L}, \omega_{H L}\right)+(1-p) V\left(y, e, d_{1}^{H}, d_{2}^{H}, \omega_{H}\right)
$$

subject to

$$
\begin{aligned}
p\left(\rho_{1} d_{1}^{H L}+d_{2}^{H L}\right)+(1-p)\left(\rho_{1} d_{1}^{H}+d_{2}^{H}\right) & \geq \rho_{0} e ; \\
\left(d_{1}^{s}, d_{2}^{s}\right) & \geq 0 ; s=H L, H \\
e & \geq 0 .
\end{aligned}
$$

The solution to the above problem provides the first-best values for $\left(y, e, d_{1}^{H L}, d_{2}^{H L}, d_{1}^{H}, d_{2}^{H}\right)$, while first-best consumption levels are given by

$$
c_{t}^{s}=C_{t}\left(y, e, d_{1}^{s}, d_{2}^{s}, \omega_{s}\right) .
$$

Proof of Proposition 1. The proof is given assuming $e>0$. In the trivial case $e=0$ the proof follows similar steps with the understanding that $d_{t}^{s}=0$ for all $s$ and $t$. Notice that positive rollover cannot be optimal in both states $H L$ and $H$ as, in this case, keeping the level of capital and the payouts to investors constant, it would be possible to slightly increase the investment in the long asset without affecting the first-period consumptions levels of depositors. The additional returns could, however, be used to increase secondperiod consumption levels, clearly yielding a better allocation. Let $\eta$ be the Lagrange multipliers for (11). Using Lemma 1 and noting that at the optimum $c_{t}^{s}=C\left(y, e, d_{1}^{s}, d_{2}^{s}, \omega_{s}\right)$, first order conditions are

$$
\begin{aligned}
p u^{\prime}\left(c_{1}^{H L}\right)+(1-p) u^{\prime}\left(c_{1}^{H}\right) & =R\left(p u^{\prime}\left(c_{2}^{H L}\right)+(1-p) u^{\prime}\left(c_{2}^{H}\right)\right) \\
R\left(p u^{\prime}\left(c_{2}^{H L}\right)+(1-p) u^{\prime}\left(c_{2}^{H}\right)\right) & =\eta \rho_{0} \\
u^{\prime}\left(c_{1}^{s}\right) & \geq \eta \rho_{1} \\
d_{1}^{s}\left(u^{\prime}\left(c_{1}^{s}\right)-\eta \rho_{1}\right) & =0 \\
u^{\prime}\left(c_{2}^{s}\right) & \geq \eta \\
d_{2}^{s}\left(u^{\prime}\left(c_{2}^{s}\right)-\eta\right) & =0 .
\end{aligned}
$$


From (15) we have $\eta>0$, so that $p\left(\rho_{1} d_{1}^{H L}+d_{2}^{H L}\right)+(1-p)\left(\rho_{1} d_{1}^{H}+d_{2}^{H}\right)=\rho_{0} e$. Since $e>0, d_{t}^{s}$ cannot be zero for all $s$ and $t$. Notice that with fixed $t$ it is impossible that $d_{t}^{H}$ and $d_{t}^{H L}$ are both strictly positive. In fact, if $d_{1}^{H}>0$ and $d_{1}^{H L}>0,(17)$ implies that $u^{\prime}\left(c_{1}^{H}\right)=u^{\prime}\left(c_{1}^{H L}\right)=\eta \rho_{1}$ which is incompatible with (14) and (15) taken together. Similarly, if $d_{2}^{H}>0$ and $d_{2}^{H L}>0,(19)$ implies that $u^{\prime}\left(c_{2}^{H}\right)=u^{\prime}\left(c_{2}^{H L}\right)=\eta$ which is incompatible with (15).

The proof is now organized in three steps.

Step 1 shows that we always have $d_{1}^{H}=0$ and $d_{2}^{H L}=0$. First, assume by contradiction that $d_{1}^{H}>0$, which immediately implies $d_{1}^{H L}=0$. Moreover, (16) - (17) imply $c_{1}^{H L} \leq c_{1}^{H}$, and from Lemma 2 we must have

$$
\begin{aligned}
c_{1}^{H L} & =\min \left\{\frac{y}{\omega_{H L}}, y+R(1+e-y)-d_{2}^{H L}\right\} \\
& \leq \min \left\{\frac{y-d_{1}^{H}}{\omega_{H}}, y+R(1+e-y)-d_{1}^{H}-d_{2}^{H}\right\}=c_{1}^{H},
\end{aligned}
$$

which is possible only if there is positive rollover in states $H L$ and $L H$. It follows that

$$
\begin{aligned}
c_{1}^{H L} & =y+R(1+e-y)-d_{2}^{H L} \leq \\
c_{1}^{H} & \leq y+R(1+e-y)-d_{1}^{H}-d_{2}^{H},
\end{aligned}
$$

which in turn implies $d_{2}^{H L} \geq d_{1}^{H}+d_{2}^{H}>0$. As a consequence, (18) - (19) imply $c_{2}^{H} \leq c_{2}^{H L}$, and given that there must be rollover in states $H L$ and $L H$, Lemma 2 implies

$$
\begin{aligned}
y+R(1+e-y)-d_{1}^{H}-d_{2}^{H} & \leq c_{2}^{H} \leq \\
c_{2}^{H L} & =y+R(1+e-y)-d_{2}^{H L}
\end{aligned}
$$

which in turn implies $d_{2}^{H L} \leq d_{1}^{H}+d_{2}^{H}$. It follows that $d_{2}^{H L}=d_{1}^{H}+d_{2}^{H}$. Hence, $d_{2}^{H}<d_{2}^{H L}$ and we therefore have

$$
\begin{aligned}
\frac{R(1+e-y)-d_{2}^{H}}{1-\omega_{H}} & >\frac{R(1+e-y)-d_{2}^{H L}}{1-\omega_{H L}}> \\
y+R(1+e-y)-d_{2}^{H L} & =y+R(1+e-y)-d_{1}^{H}-d_{2}^{H},
\end{aligned}
$$

meaning that there must also be positive rollover in state $H$, which is clearly a contradiction. The assumption $d_{2}^{H L}>0$ leads to a similar contradiction, so that it must be $d_{1}^{H}=0$ and $d_{2}^{H L}=0$ as claimed.

Step 2 establishes that positive rollover is impossible in state $H$. Assume by contradiction that we do have positive rollover in state $H$. It follows that $c_{1}^{H}=c_{2}^{H}$ and (16), (18), 
and (19) imply $d_{2}^{H}=0$. Hence $d_{1}^{H L}=e \rho_{0} / \rho_{1}>0$ is the only positive payout to investors, and (16) - (17) imply $c_{1}^{H L} \geq c_{1}^{H}$. Now we have

$$
y+R(1+e-y)-d_{1}^{H L} \geq c_{1}^{H L} \geq c_{1}^{H}=y+R(1+e-y),
$$

which is clearly a contradiction as $d_{1}^{H L}>0$.

Step 3 shows how consumption levels are ordered. From Lemma 2 we know that $c_{1}^{H L} \leq c_{2}^{H L}$ and this weak inequality holds as an equality if and only if there is positive rollover in states $H L$ and $L H$. It is therefore sufficient to show that $c_{1}^{H}<c_{2}^{H L}$ and $c_{2}^{H L}<c_{2}^{H}$. We distinguish three cases.

(i) $d_{2}^{H}>0$ and $d_{1}^{H L}>0$. In this case, (18) and (19) with $d_{2}^{H}>0$ imply $c_{2}^{H L} \leq c_{2}^{H}$ and the inequality must be strict as we would otherwise have $u^{\prime}\left(c_{2}^{H L}\right)=u^{\prime}\left(c_{2}^{H}\right)=\eta$ which is incompatible with (15). Similarly, (16) and (17) with $d_{1}^{H L}>0$ imply $c_{1}^{H} \leq c_{1}^{H L}$, and the inequality must be strict as we would otherwise have $u^{\prime}\left(c_{1}^{H L}\right)=u^{\prime}\left(c_{1}^{H}\right)=\eta \rho_{1}$, which is incompatible with (14) and (15) taken together.

(ii) $d_{2}^{H}>0$ and $d_{1}^{H L}=0$. In this case, $c_{2}^{H L}<c_{2}^{H}$ follows from $d_{2}^{H}>0$ as in (i). Furthermore, if there is no rollover in states $H L$ and $L H$ we immediately have

$$
c_{1}^{H}=\frac{y}{\omega_{H}}<\frac{y}{\omega_{L}}=c_{1}^{H L},
$$

whereas in the case of rollover in states $H L$ and $L H$ we obtain

$$
c_{1}^{H L}=c_{2}^{H L}=y+(1+e-y) R>y+(1+e-y) R-d_{2}^{H} \geq c_{1}^{H} .
$$

(iii) $d_{2}^{H}=0$ and $d_{1}^{H L}>0$. In this case, $c_{1}^{H}<c_{1}^{H L}$ follows from $d_{1}^{H L}>0$ as in (i). Furthermore, if there is no rollover in state $H L$ we immediately have

$$
c_{2}^{H L}=\frac{(1+e-y) R}{1-\omega_{H L}}<\frac{(1+e-y) R}{1-\omega_{H}}=c_{2}^{H},
$$

whereas in the case of rollover in states $H L$ and $L H$ we obtain

$$
c_{2}^{H L}=c_{1}^{H L}=y+(1+e-y) R-d_{1}^{H L}<y+(1+e-y) R \leq c_{2}^{H} .
$$

\section{Appendix B: Variable Description}

Table B1 reports the detailed description and how the variables have been constructed using the SDI dataset, and their respective call report codes. 
[TABLE B1]

Table B2 presents unconditional pair-wise correlations of all the variables used in the regressions.

[TABLE B2] 


\section{References}

[1] Admati, A., P. DeMarzo, M. Hellwig and P. Pfleiderer (2010), "Fallacies, Irrelevant Facts, and Myths in the Discussion of Capital Regulation: Why Bank Equity is Not Expensive", Stanford GSB Research Paper No. 2065.

[2] Acharya, V. and T. Yorulmazer (2007), "Too Many to Fail - An Analysis of Timeinconsistency in Bank Closure Policies", Journal of Financial Intermediation, 16, $1-31$.

[3] Afonso, G., A. Kovner and A. Schoar (2011), "Stressed, not Frozen: The Federal Funds Market in the Financial Crisis", Journal of Finance, 66(4): 1109-1139.

[4] Allen, F., E. Carletti and R. Marquez (2011), "Credit Market Competition and Capital Regulation", Review of Financial Studies, 24(4): 983-1018.

[5] Allen, F. and D. Gale (2000), "Financial Contagion", Journal of Political Economy, 108: 1-33.

[6] Allen, F. and D. Gale (2007), "Understanding Financial Crises", Oxford University Press, Oxford.

[7] Berger, A., R. DeYoung, M. Flannery, D. Lee and O. Oztekin (2008), "How Do Large Banking Organizations Manage Their Capital Ratios?", Journal of Financial Services Research, 34: 123-149.

[8] Bhattacharya, S. and D. Gale (1987), "Preference Shocks, Liquidity and Central Bank Policy" in W. Barnett and K. Singleton (eds.), New Approaches to Monetary Economics, Cambridge University Press, Cambridge.

[9] Besanko, D. and G. Kanatas (1996), "The Regulation of Bank Capital: Do Capital Standards Promote Bank Safety?", Journal of Financial Intermediation, 5: 160-183.

[10] Brusco, S. and F. Castiglionesi (2007), "Liquidity Coinsurance, Moral Hazard and Financial Contagion", Journal of Finance, 62 (5): 2275-2302.

[11] Castiglionesi, F., F. Feriozzi, and G. Lorenzoni (2010), "Financial Integration and Liquidity Crises", Manuscript, MIT and Tilburg University. 
[12] Cocco, J., Gomes F. and N. Martins (2009), "Lending Relationships in the Interbank Market", Journal of Financial Intermediation, 18: 24-48.

[13] Diamond, D., and P. Dybvig (1983), "Bank Runs, Deposit Insurance and Liquidity", Journal of Political Economy, 91: 401-419.

[14] Diamond, D. and R. Rajan (2000), "A Theory of Bank Capital", Journal of Finance, 55(6): 2431-2465.

[15] Flannery, M. and K. Rangan (2008), "What Caused the Bank Capital Build-up of the 1990s?", Review of Finance, 12: 391-429.

[16] Furfine, C. H. (2000), "Interbank Payments and the Daily Federal Funds Rate", Journal of Monetary Economics, 46: 535-553.

[17] Furfine, C. H. (2001), "Banks as Monitors of Other Banks: Evidence from the Overnight Federal Funds Market", The Journal of Business, 74: 33-57.

[18] Furfine, C. H. (2002), "The Interbank Market During a Crisis", European Economic Review, 46: 809-820.

[19] Furlong, F. and M. Keeley (1989), "Capital Regulation and Bank Risk-Taking: A Note", Journal of Banking and Finance, 13: 883-891.

[20] Gale, D. (2004), "Notes on Optimal Capital Regulation" in P. St-Amant and C. Wilkins (eds.), The Evolving Financial System and Public Policy, Bank of Canada, Ottawa.

[21] Genotte, G. and D. Pyle (1991), "Capital Controls and Bank Risk", Journal of Banking and Finance, 15: 805-824.

[22] Gropp, R. and F. Heider (2010), "The Determinants of Bank Capital Structure", Review of Finance, 14: 1-36.

[23] Hellman, T. F., K. Murdock and J. Stiglitz (2000) "Liberalization, Moral Hazard in Banking and Prudential Regulation: Are Capital Requirements Enough?", American Economic Review, 90(1), 147-165.

[24] Kim, D. and A. Santomero (1988), "Risk in Banking and Capital Regulation", Journal of Finance, 43: 1219-1233. 
[25] Morrison, A. and L. White (2005), "Crises and Capital Requirements in Banking", American Economic Review, 95(5): 1548-1572.

[26] Nijkens, R. and W. Wagner (2011), "Credit Risk Transfer Activities and Systematic Risk: How Banks Became Less Risky Individually but Posed Greater Risks to the Financial System at the Same Time", Journal of Banking and Finance, 35: 13911398.

[27] Petersen, M. (2009), "Estimating Standard Errors in Finance Panel Data Sets: Comparing Approaches", Review of Financial Studies, 22: 435-480. 
Figure 1 - Bank capital and payouts for different values of $p$

(a) Bank capital over total assets

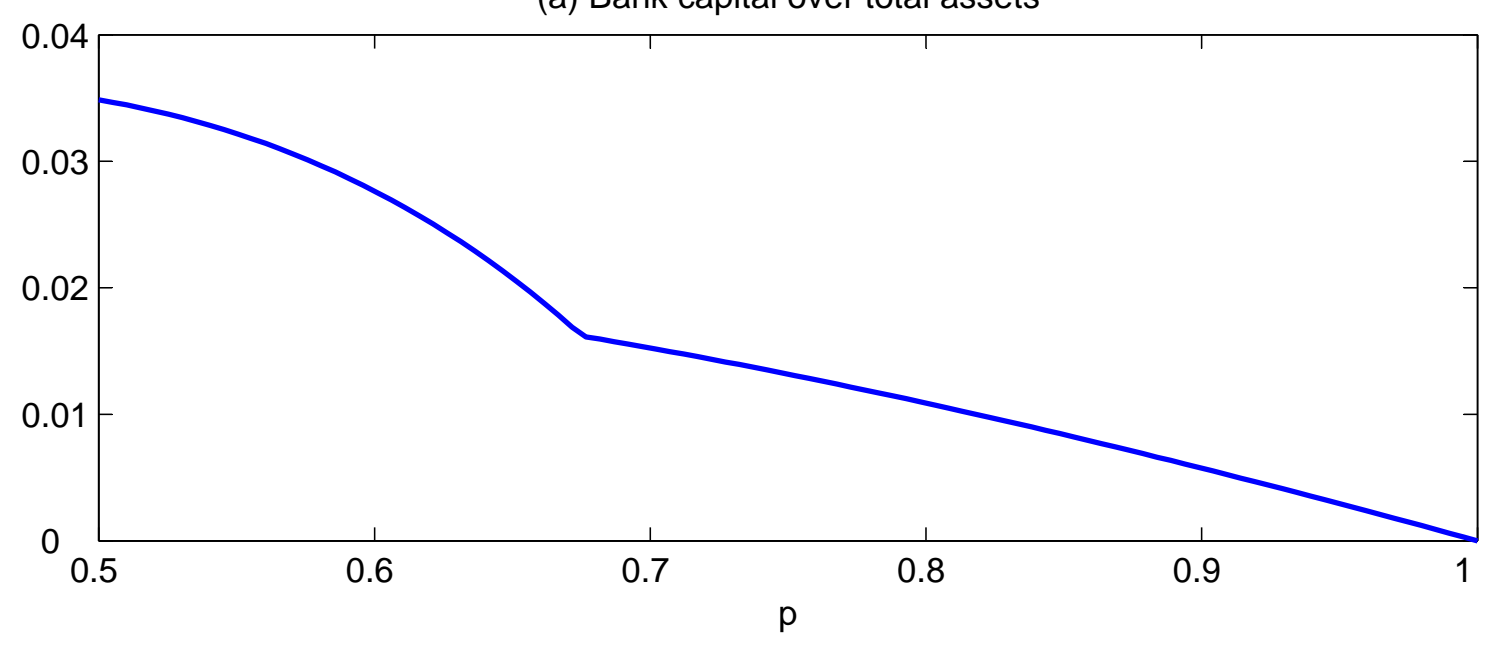

(b) Payouts to investors

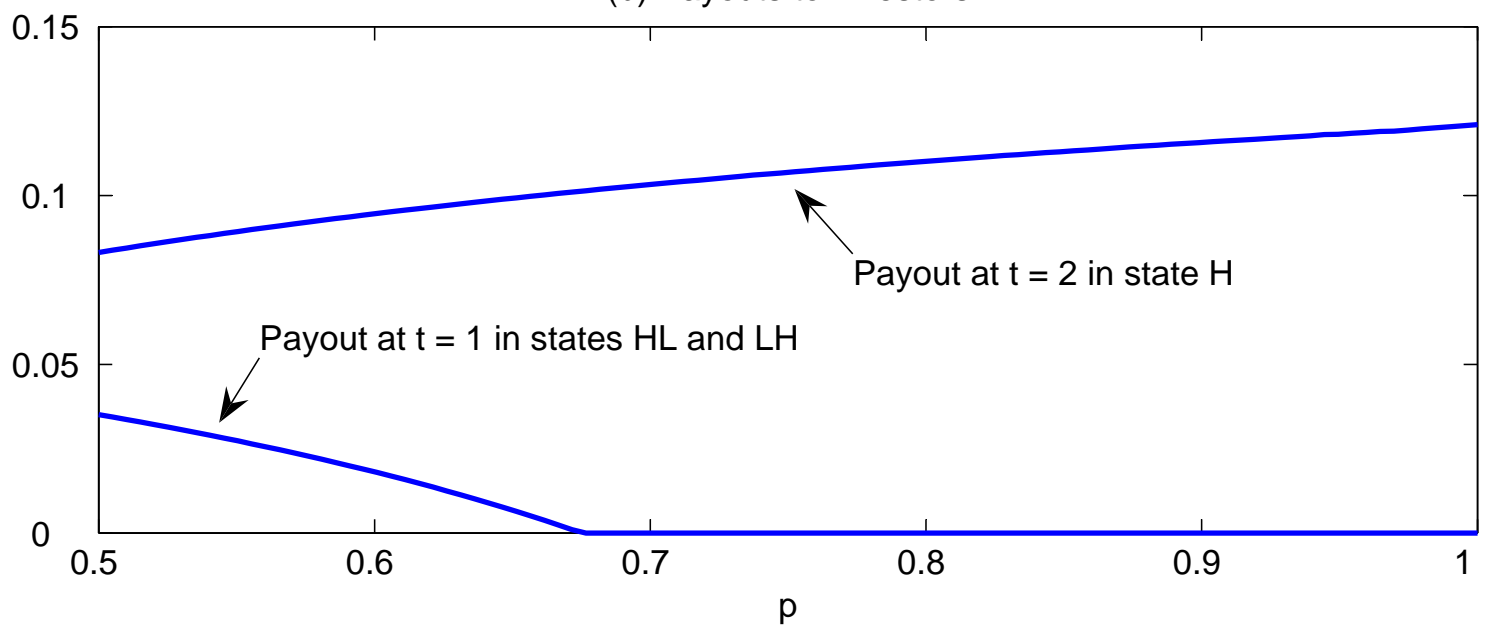

Note: This numerical example assumes a constant relative risk aversion of 2. Other parameters are $R=1.8, \rho_{0}=2$, $\rho_{1}=1.75, \omega_{H}=0.6$, and $\omega_{L}=0.4$. 
Figure 2 - Bank capital and consumption volatility for different values of $p$

(a) Bank capital over total assets

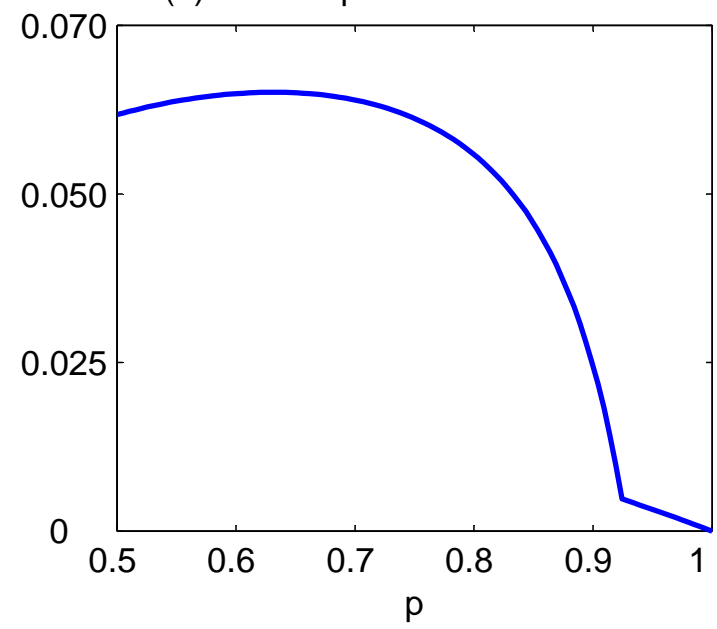

(c) Consumption volatility at $\mathrm{t}=1$

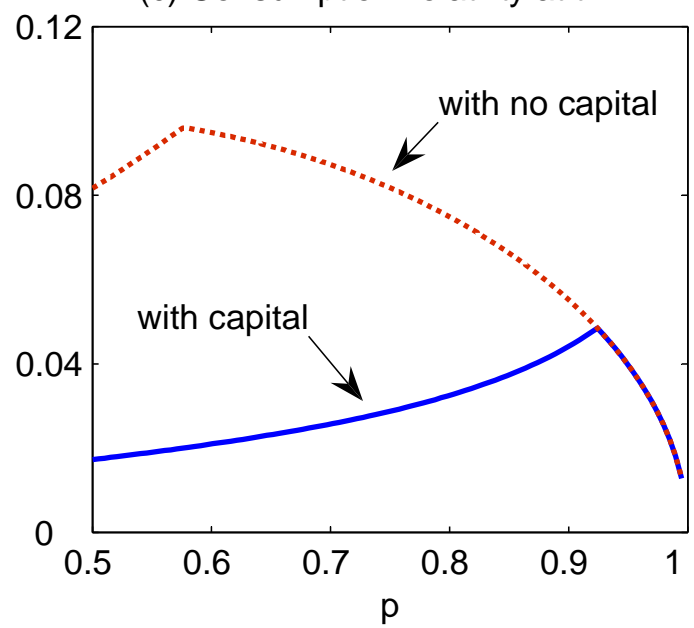

(b) Liquidity ratio

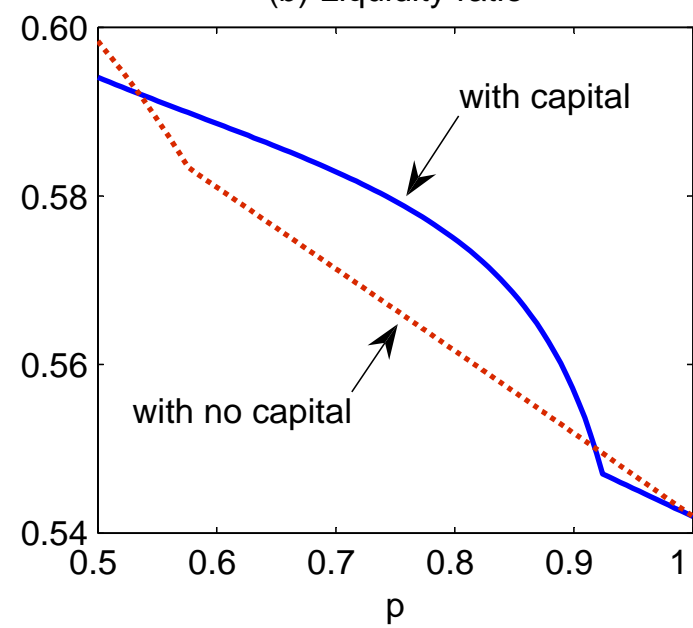

(c) Consumption volatility at $\mathrm{t}=2$

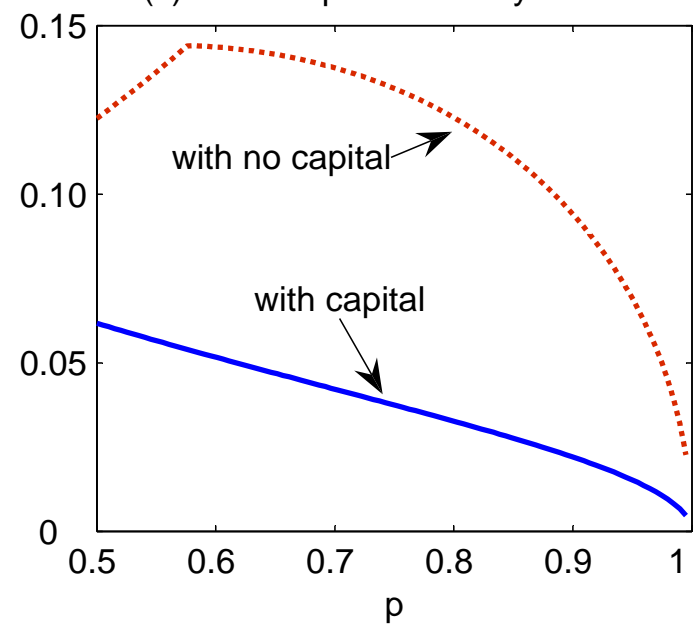

Note: This numerical example assumes a constant relative risk aversion of 2. Other parameters are $R=1.4, \rho_{0}=$ $1.55, \rho_{1}=1.50, \omega_{H}=0.6$, and $\omega_{L}=0.4$. 
Table 2 - Summary statistics

\begin{tabular}{lccccc}
\hline Variable & Mean & Stan. Dev. & p5\% & Median & p95\% \\
\hline Capital & 0.100 & 0.052 & 0.064 & 0.089 & 0.162 \\
Interbank & 0.025 & 0.039 & 0.001 & 0.015 & 0.085 \\
Fed Funds Repos & 0.063 & 0.075 & 0.000 & 0.042 & 0.199 \\
Deposits Fed & 0.006 & 0.010 & 0.000 & 0.002 & 0.024 \\
LLP & 0.002 & 0.008 & 0.000 & 0.001 & 0.005 \\
Liquidity & 0.207 & 0.131 & 0.019 & 0.192 & 0.443 \\
Loans & 0.630 & 0.157 & 0.346 & 0.647 & 0.847 \\
Deposits & 0.745 & 0.141 & 0.515 & 0.774 & 0.891 \\
ROA & 0.008 & 0.011 & 0.001 & 0.006 & 0.017 \\
Size (\$ million) & 2,572 & 24,000 & 109 & 342 & 5,859 \\
\hline
\end{tabular}

Note: The sample consists of 5,871 banks and 124,406 observations from 1995Q1 to 2007Q2. Data is obtained from SDI repository database. 
Figure 3 - Aggregate capital ratio and aggregate interbank activity

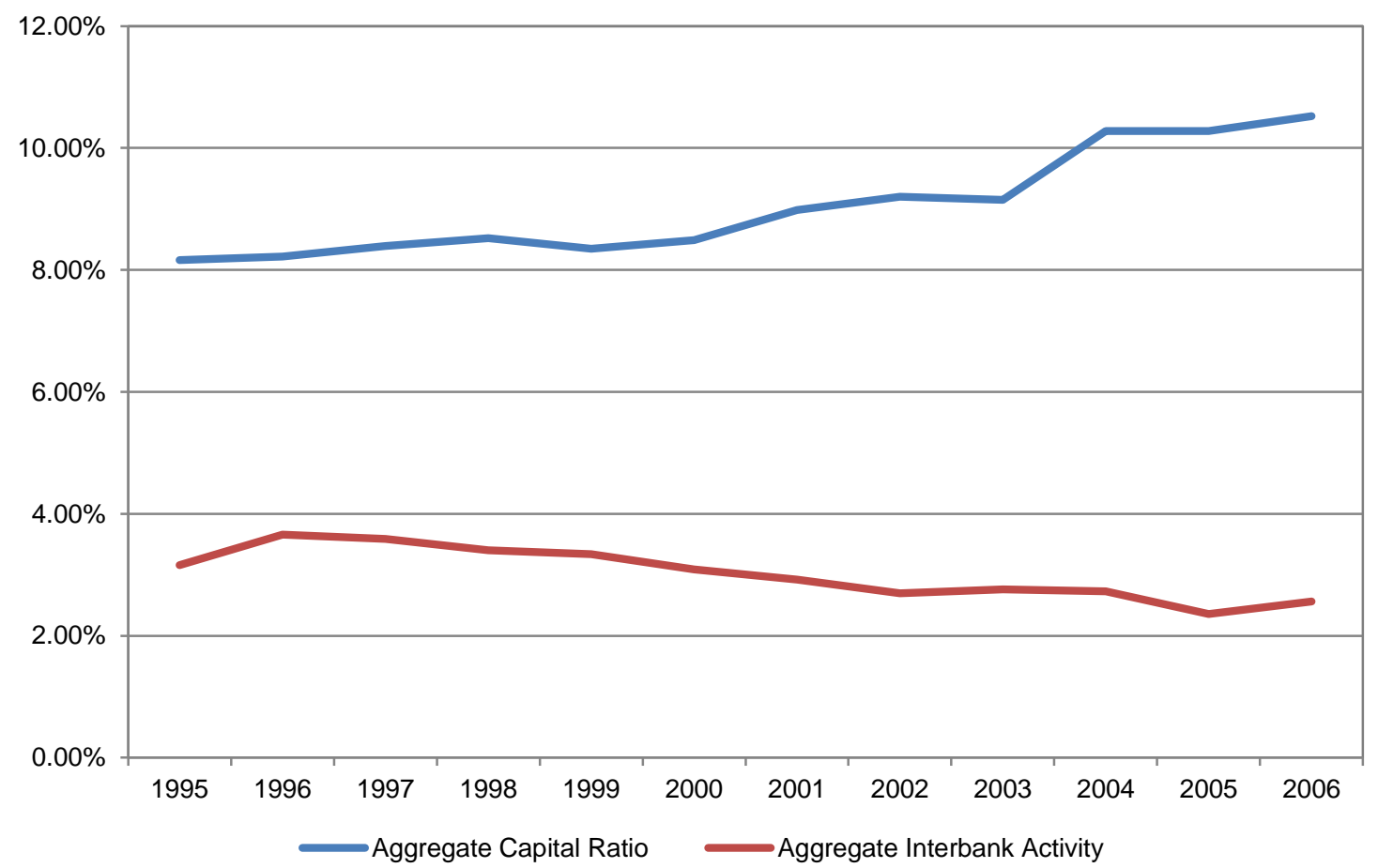

Note: This Figure reports the aggregate measures of bank capital ratios and interbank activity between 1995 and 2006 in the U.S. banking system. The Aggregate Capital Ratio in a given year is the sum of total equity capital for all commercial banks in the U.S. in that year, as reported in the SDI database, divided by the sum of banks total assets for the same year. Similarly, the Aggregate Interbank Activity in a certain year is the sum of balances due from depository institutions and deposits from depository institutions for all banks in the SDI database in that year, divided by the sum of banks total assets for the same year.

Table 3 - Principal component analysis

\begin{tabular}{l|ccccccc}
\hline & $\mathbf{1 9 9 5} \mathbf{Q 1}$ & $\mathbf{1 9 9 7} \mathbf{Q 1}$ & $\mathbf{1 9 9 9} \mathbf{Q 1}$ & $\mathbf{2 0 0 1} \mathbf{Q 1}$ & $\mathbf{2 0 0 3} \mathbf{Q 1}$ & $\mathbf{2 0 0 5} \mathbf{Q 1}$ & $\mathbf{2 0 0 7} \mathbf{Q 1}$ \\
& $\mathbf{1 9 9 6} \mathbf{Q 4}$ & $\mathbf{1 9 9 8} \mathbf{Q 4}$ & $\mathbf{2 0 0 0} \mathbf{Q 4}$ & $\mathbf{2 0 0 2} \mathbf{Q 4}$ & $\mathbf{2 0 0 4} \mathbf{Q 4}$ & $\mathbf{2 0 0 6} \mathbf{Q 4}$ & $\mathbf{2 0 0 8} \mathbf{Q 4}$ \\
\hline Commonality of Deposits & $39.50 \%$ & $40.11 \%$ & $41.04 \%$ & $43.62 \%$ & $41.73 \%$ & $43.66 \%$ & $43.71 \%$ \\
Aggregate Capital Ratio & $8.16 \%$ & $8.39 \%$ & $8.35 \%$ & $8.98 \%$ & $9.15 \%$ & $10.28 \%$ & $10.34 \%$ \\
Aggregate Interbank Activity & $3.16 \%$ & $3.59 \%$ & $3.34 \%$ & $2.92 \%$ & $2.76 \%$ & $2.36 \%$ & $2.78 \%$ \\
\hline Number of banks & 3,002 & 2,898 & 3,111 & 1,133 & 1,273 & 1,464 & 1,786 \\
\hline
\end{tabular}

Note: Commonality of Deposit corresponds to the percentage of the overall variability of deposits explained by the First Principal Component. Aggregate Capital Ratio is the sum of total equity capital at the end of the second year of each sub-period for all commercial banks in the U.S. as reported in the SDI database, divided by the sum of their total assets. Aggregate Interbank Activity is the sum of balances due from depository institutions and deposits from depository institutions divided by the sum of banks total assets, for all banks in the SDI database at the end of the second year of each sub-period. The last raw contains the number of banks used to perform the principal component analysis, i.e., the number of banks in our sample that report all the required information for our analysis for the eight quarters in each sub-period. 
Table 4 - Bank capital and interbank activity: Panel regressions

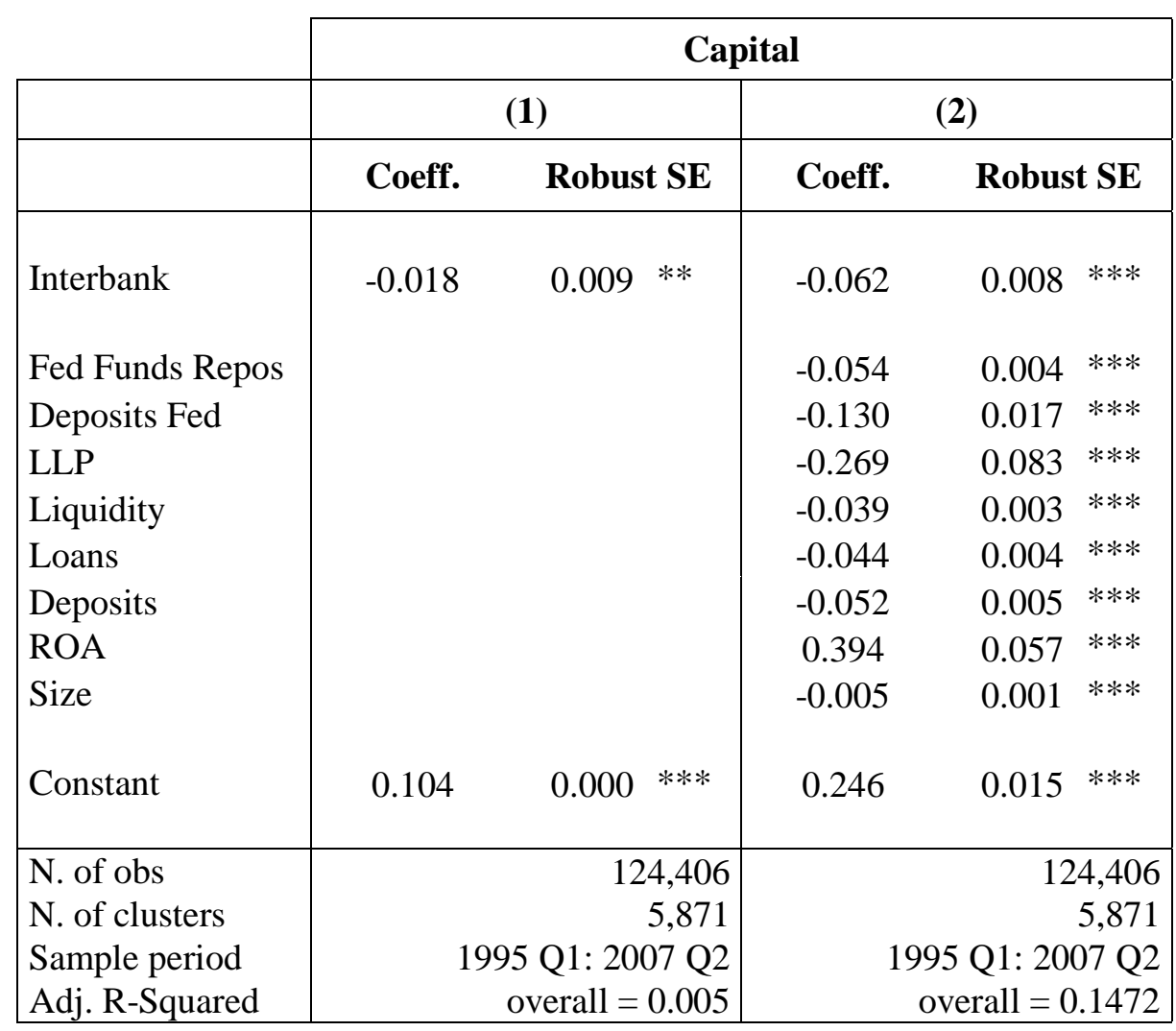

Note: The estimates are based on a panel regression of bank capital (Capital) on interbank market activity (Interbank). Interbank market activity is measured as the sum of the unsecured borrowing and lending positions of an individual bank, normalized by total assets. Definitions of the other variables are given in Table B1 in Appendix B. Extreme observations are winsorized at top and bottom 2.5\%. All regressions include bank fixed effects, and year and quarterly dummies. For each model specification we list regression coefficients, robust standard errors (clustered at the bank level), and significance levels. $* * *, * *$, and $*$ respectively denote a significance level of $1 \%, 5 \%$, and $10 \%$. 
Table 5 - Bank capital and interbank activity: Cross-sectional regressions

\begin{tabular}{|c|c|c|c|c|c|c|}
\hline & \multicolumn{6}{|c|}{ Capital } \\
\hline & \multicolumn{2}{|c|}{ (1) } & \multicolumn{2}{|c|}{ (2) } & \multicolumn{2}{|c|}{ (3) } \\
\hline & Coeff. & Robust SE & Coeff. & Robust SE & Coeff. & Robust SE \\
\hline Interbank & -0.070 & $0.018 * * *$ & -0.062 & $0.019 * * *$ & -0.070 & $0.024 * * *$ \\
\hline Fed Funds Repos & -0.086 & $0.010 * * *$ & -0.089 & $0.010 * * *$ & -0.037 & $0.015 * * *$ \\
\hline Deposits Fed & -0.173 & $0.040 * * *$ & -0.105 & $0.043 * *$ & 0.008 & 0.083 \\
\hline LLP & 0.263 & 0.170 & 1.779 & $0.502 * * *$ & 5.226 & $0.825 * * *$ \\
\hline Liquidity & -0.022 & $0.005 * * *$ & -0.059 & $0.006 * * *$ & -0.101 & $0.010 * * *$ \\
\hline Loans & -0.053 & $0.005 * * *$ & -0.076 & $0.006 * * *$ & -0.079 & $0.008 * * *$ \\
\hline Deposits & -0.087 & $0.007 * * *$ & -0.061 & $0.006 * * *$ & -0.083 & $0.008 * * *$ \\
\hline ROA & 0.976 & $0.121 * * *$ & 3.025 & $0.303 * * *$ & 0.903 & $0.378 * *$ \\
\hline Size & -0.006 & $0.000 * * *$ & -0.004 & $0.000 * * *$ & -0.004 & $0.001 * * *$ \\
\hline Constant & 0.270 & $0.011 * * *$ & 0.253 & $0.011 * * *$ & 0.284 & $0.014 * * *$ \\
\hline N. of obs & & 3,381 & & 3,611 & & 2,176 \\
\hline N. of clusters & & 3,381 & & 3,611 & & 2,176 \\
\hline Sample period & & 1995 Q4 & & 2000 Q1 & & 2006 Q1 \\
\hline R-Squared & & 0.2088 & & 0.1964 & & 0.2011 \\
\hline
\end{tabular}

Note: The estimates are based on cross-sectional regressions of bank capital on interbank market activity. Column (1) reports results for the fourth quarter of 1995. Column (2) reports the first quarter of 2000. Column (3) reports the first quarter of 2006. Interbank market activity is measured as the sum of the unsecured borrowing and lending positions of an individual bank, normalized by total assets. Definitions of the other variables are given in Table B1 in Appendix B. Extreme observations are winsorized at top and bottom 2.5\%. For each model specification we list regression coefficients, robust standard errors and significance levels. $* * *, * *$, and $*$ respectively denote a significance level of $1 \%, 5 \%$, and $10 \%$. 
Table 6 - Bank capital and interbank activity: Extended sample and crisis period

\begin{tabular}{|c|c|c|c|c|c|c|}
\hline & \multicolumn{6}{|c|}{ Capital } \\
\hline & \multicolumn{3}{|c|}{ (1) } & \multicolumn{3}{|c|}{ (2) } \\
\hline & Coeff. & \multicolumn{2}{|c|}{ Robust SE } & Coeff. & \multicolumn{2}{|c|}{ Robust SE } \\
\hline Interbank & -0.083 & 0.007 & $* * *$ & -0.097 & 0.008 & $* * *$ \\
\hline Fed Funds Repos & -0.060 & 0.004 & $* * *$ & -0.050 & 0.008 & $* * *$ \\
\hline Deposits Fed & -0.104 & 0.009 & $* * *$ & -0.104 & 0.008 & $* * *$ \\
\hline LLP & -0.038 & 0.057 & & -0.070 & 0.051 & \\
\hline Liquidity & -0.041 & 0.003 & $* * *$ & -0.030 & 0.006 & $* * *$ \\
\hline Loans & -0.047 & 0.004 & $* * *$ & -0.023 & 0.006 & $* * *$ \\
\hline Deposits & -0.059 & 0.004 & $* * *$ & -0.065 & 0.006 & $* * *$ \\
\hline ROA & 0.537 & 0.049 & $* * *$ & 0.600 & 0.050 & $* * *$ \\
\hline Size & -0.004 & 0.001 & $* * *$ & -0.013 & 0.002 & $* * *$ \\
\hline Constant & 0.232 & 0.013 & $* * *$ & 0.355 & 0.029 & $* * *$ \\
\hline N. of obs & \multicolumn{3}{|c|}{184,920} & \multicolumn{3}{|c|}{46,721} \\
\hline N. of clusters & \multicolumn{3}{|c|}{6,858} & \multirow{3}{*}{\multicolumn{3}{|c|}{$\begin{array}{r}3,057 \\
\text { 2007 Q3: } 2012 \text { Q4 } \\
\text { overall }=0.0295\end{array}$}} \\
\hline Sample period & \multirow{2}{*}{\multicolumn{3}{|c|}{$\begin{array}{r}1995 \text { Q1: } 2012 \text { Q4 } \\
\text { overall }=0.1627\end{array}$}} & & & \\
\hline Adj. R-Squared & & & & & & \\
\hline
\end{tabular}

Note: The estimates are based on a panel regression of bank capital on interbank market activity. The regression in Column (1) is based on an extended sample which includes the crisis period (1995Q1 - 2012Q4). Column (2) reports regression results based on the crisis period alone (2007Q3 - 2012Q4). Interbank market activity is measured as the sum of the unsecured borrowing and lending positions of an individual bank, normalized by total assets. Definitions of the other variables are given in Table B1 in Appendix B. All regressions include bank fixed effects, and year and quarterly dummies. Extreme observations are winsorized at top and bottom $2.5 \%$. For each model specification we list regression coefficients, robust standard errors (clustered at the bank level), and significance levels. ***, **, and * respectively denote a significance level of $1 \%, 5 \%$, and $10 \%$. 
Table 7 - Bank capital and interbank activity: Net lender and net borrower

\begin{tabular}{|c|c|c|c|c|c|}
\hline & \multicolumn{5}{|c|}{ Capital } \\
\hline & \multicolumn{3}{|c|}{ (1) } & \multicolumn{2}{|c|}{ (2) } \\
\hline & Coeff. & Robus & t SE & Coeff. & Robust SE \\
\hline Interbank & -0.033 & 0.009 & $* * *$ & -0.114 & $0.019 * * *$ \\
\hline Fed Funds Repos & -0.055 & 0.005 & $* * *$ & -0.049 & $0.009 * * *$ \\
\hline Deposits Fed & -0.124 & 0.019 & $* * *$ & -0.084 & $0.025 * * *$ \\
\hline LLP & -0.230 & 0.093 & $* *$ & -0.433 & $0.132 * * *$ \\
\hline Liquidity & -0.033 & 0.003 & $* * *$ & -0.054 & $0.007 * * *$ \\
\hline Loans & -0.037 & 0.004 & $* * *$ & -0.061 & $0.008 * * *$ \\
\hline Deposits & -0.055 & 0.005 & $* * *$ & -0.038 & $0.009 * * *$ \\
\hline ROA & 0.391 & 0.060 & $* * *$ & 0.371 & $0.107 * * *$ \\
\hline Size & -0.005 & 0.001 & $* * *$ & -0.007 & $0.002 * * *$ \\
\hline Constant & 0.248 & 0.017 & $* * *$ & 0.259 & $0.028 * * *$ \\
\hline N. of obs & & & 2,975 & & 21,048 \\
\hline N. of clusters & & & 5,563 & & 2,168 \\
\hline Sample period & & Q1: 200 & $07 \mathrm{Q} 2$ & & Q1: 2012 Q4 \\
\hline Adj. R-Squared & & erall $=0$ & .1480 & & erall $=0.0912$ \\
\hline
\end{tabular}

Note: The estimates are based on a panel regression of bank capital on interbank market activity. Regression in Column (1) is based on the sample that includes banks that are net lenders on the unsecured interbank market, i.e. banks with more assets than liabilities on this market. Column (2) reports regression results for the banks that are instead net borrowers on the unsecured interbank market, i.e. banks with more liabilities than assets on this market. Interbank market activity is measured as the sum of the unsecured borrowing and lending positions of an individual bank, normalized by total assets. i.e. banks with more assets than liabilities on this market. Definitions of the other variables are given in Table B1 in Appendix B. Extreme observations are winsorized at top and bottom 2.5\%. All regressions include bank fixed effects, and year and quarterly dummies. For each model specification we list regression coefficients, robust standard errors (clustered at the bank level), and significance levels. ***, **, and * respectively denote a significance level of $1 \%, 5 \%$, and $10 \%$. 
Table 8 - Bank capital and interbank activity: Bank size

\begin{tabular}{|c|c|c|c|c|c|c|c|c|c|c|c|c|}
\hline & \multicolumn{12}{|c|}{ Capital } \\
\hline & \multicolumn{3}{|c|}{ (1) } & \multicolumn{3}{|c|}{ (2) } & \multicolumn{3}{|c|}{ (3) } & \multicolumn{3}{|c|}{ (4) } \\
\hline & Coeff. & \multicolumn{2}{|c|}{ Robust SE } & Coeff. & \multicolumn{2}{|c|}{ Robust SE } & Coeff. & \multicolumn{2}{|c|}{ Robust SE } & Coeff. & \multicolumn{2}{|c|}{ Robust SE } \\
\hline Interbank & -0.058 & 0.008 & $* * *$ & -0.066 & 0.014 & $* * *$ & -0.061 & 0.016 & $* * *$ & -0.252 & 0.125 & $* *$ \\
\hline Fed Funds Repos & -0.036 & 0.004 & $* * *$ & -0.056 & 0.006 & $* * *$ & -0.074 & 0.009 & $* * *$ & -0.157 & 0.043 & $* * *$ \\
\hline Deposits Fed & -0.076 & 0.017 & $* * *$ & -0.058 & 0.022 & $* * *$ & -0.121 & 0.035 & & 0.018 & 0.129 & \\
\hline LLP & -0.163 & 0.074 & $* *$ & -0.214 & 0.112 & $*$ & -0.378 & 0.158 & $* * *$ & -0.267 & 0.284 & \\
\hline Liquidity & -0.021 & 0.003 & $* * *$ & -0.037 & 0.005 & $* * *$ & -0.061 & 0.008 & $* * *$ & -0.261 & 0.076 & $* * *$ \\
\hline Loans & -0.031 & 0.004 & $* * *$ & -0.038 & 0.006 & $* * *$ & -0.055 & 0.009 & $* * *$ & -0.224 & 0.071 & $* * *$ \\
\hline Deposits & -0.057 & 0.006 & $* * *$ & -0.048 & 0.007 & $* * *$ & -0.047 & 0.009 & $* * *$ & -0.045 & 0.055 & \\
\hline ROA & 0.257 & 0.057 & $* * *$ & 0.460 & 0.082 & $* * *$ & 0.111 & 0.119 & & -0.484 & 0.471 & \\
\hline Size & -0.029 & 0.002 & $* * *$ & -0.015 & 0.002 & $* * *$ & -0.003 & 0.002 & & 0.016 & 0.011 & \\
\hline Constant & 0.519 & 0.025 & $* * *$ & 0.351 & 0.027 & $* * *$ & 0.214 & 0.033 & $* * *$ & 0.021 & 0.172 & \\
\hline N. of obs & \multicolumn{3}{|c|}{56,025} & \multicolumn{3}{|c|}{45,483} & \multicolumn{3}{|c|}{21,955} & \multicolumn{3}{|r|}{943} \\
\hline N. of clusters & \multicolumn{3}{|c|}{4,280} & \multicolumn{3}{|c|}{2,690} & \multicolumn{3}{|c|}{1,157} & \multicolumn{3}{|c|}{50} \\
\hline $\begin{array}{l}\text { Sample period } \\
\text { R-Squared }\end{array}$ & \multicolumn{3}{|c|}{$\begin{array}{r}1995 \mathrm{Q} 1: 2007 \mathrm{Q} 2 \\
\text { overall }=0.1250\end{array}$} & \multicolumn{3}{|c|}{$\begin{array}{r}1995 \mathrm{Q} 1: 2007 \mathrm{Q} 2 \\
\text { overall }=0.0800\end{array}$} & \multicolumn{3}{|c|}{$\begin{array}{r}1995 \mathrm{Q} 1: 2007 \mathrm{Q} 2 \\
\text { overall }=0.1440\end{array}$} & \multicolumn{3}{|c|}{$\begin{array}{r}1995 \text { Q1: } 2007 \text { Q2 } \\
\text { overall }=0.0497\end{array}$} \\
\hline
\end{tabular}

Note: The estimates are based on a panel regression of bank capital on interbank market activity. The sample is split into banks with total assets lower than $\$ 300$ million (Column 1), banks with total assets between $\$ 300$ million and $\$ 1$ billion (Column 2), banks with total assets between $\$ 1$ billion and $\$ 50$ billion (Column 3), and banks with total assets larger than $\$ 50$ billion (Column 4). Interbank market activity is measured as the sum of the unsecured borrowing and lending positions of an individual bank, normalized by total assets. Definitions of the other variables are given in Table B1 in Appendix B. All regressions include bank fixed effects, and year and quarterly dummies. Extreme observations are winsorized at top and bottom $2.5 \%$. For each model specification we list regression coefficients, robust standard errors (clustered at the bank level), and significance levels. ***, **, and * respectively denote a significance level of $1 \%, 5 \%$, and $10 \%$. 
Table B1 - Variable descriptions

\begin{tabular}{|c|c|c|c|}
\hline Variable & $\begin{array}{l}\text { Ref. code of } \\
\text { the SDI (FDIC) } \\
\text { data item }\end{array}$ & $\begin{array}{l}\text { Ref. Codes } \\
\text { Call Reports } \\
\text { FFIEC031 } \\
\text { (FFIEC041) }\end{array}$ & Definition of Variable and Description of the SDI (FDCI) data item \\
\hline \multirow[t]{2}{*}{ Capital } & & & 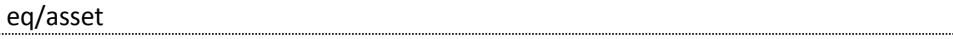 \\
\hline & eq & riad3210 & $\begin{array}{l}\text { Total bank equity capital (includes preferred and common stock, surplus and } \\
\text { undivided profits). }\end{array}$ \\
\hline Interbank & & & (chus + chnus + trncbo + ntrcomot $+\operatorname{trnfc}+n t r f c+t r n f g+n t r f g) / a s s e t$ \\
\hline \multirow[t]{2}{*}{ - Assets } & chus & $\begin{array}{l}\text { rcfd0083 } \\
\text { (rcon0083) } \\
\text { rcfd0085 } \\
\text { (rcon0085) }\end{array}$ & $\begin{array}{l}\text { Cash balances due from depository institutions in the U.S. Include all interest- } \\
\text { bearing and noninterest-bearing balances whether in the form of demand, savings } \\
\text { or time balances, including certificates of deposit but excluding certificates of } \\
\text { deposit held for trading. }\end{array}$ \\
\hline & chnus & $\begin{array}{l}\text { rcfd0073 } \\
(\text { rcon0073) } \\
\text { rcfd0074 } \\
(\text { rcon0074) }\end{array}$ & Cash balances due from banks in foreign countries and foreign central banks. \\
\hline \multirow[t]{6}{*}{ - Liabilities } & trncbo & rconb551 & $\begin{array}{l}\text { Transaction accounts of commercial banks and other depository institutions in the } \\
\text { U.S. }\end{array}$ \\
\hline & ntrcomot & rconb552 & $\begin{array}{l}\text { Nontransaction accounts of commercial banks and other depository institutions in } \\
\text { the U.S. held in domestic offices. }\end{array}$ \\
\hline & $\operatorname{trnfc}$ & rcon2213 & $\begin{array}{l}\text { Total transaction accounts of banks in foreign countries held in domestic offices. } \\
\text { This item is not reported by institutions with less than } \$ 100 \text { million in total assets. }\end{array}$ \\
\hline & ntrfc & rcon2236 & $\begin{array}{l}\text { Total nontransaction accounts of banks in foreign countries held in domestic } \\
\text { offices. }\end{array}$ \\
\hline & $\operatorname{trnfg}$ & rcon2216 & $\begin{array}{l}\text { Total transaction accounts of foreign governments and official institutions (includes } \\
\text { foreign central banks) held in domestic offices. }\end{array}$ \\
\hline & ntrfg & rcon2377 & $\begin{array}{l}\text { Total nontransaction accounts of foreign governments and official institutions } \\
\text { (includes foreign central banks) held in domestic offices. }\end{array}$ \\
\hline Fed Funds Repos & & & (frepo + frepp)/asset \\
\hline - Assets & frepo & $\begin{array}{l}\text { rconb987 } \\
\text { rcfdb989 } \\
\text { (rconb989) }\end{array}$ & $\begin{array}{l}\text { Total federal funds sold and securities purchased under agreements to resell in } \\
\text { domestic offices. }\end{array}$ \\
\hline - Liabilities & frepp & $\begin{array}{l}\text { rconb993 } \\
\text { rcfdb995 } \\
\text { (rconb995) }\end{array}$ & $\begin{array}{l}\text { Total federal funds purchased and securities sold under agreements to repurchase } \\
\text { in domestic offices. }\end{array}$ \\
\hline \multirow[t]{2}{*}{ Deposits Fed } & & & chfrb/asset \\
\hline & chfrb & $\begin{array}{l}\text { rcfd0090 } \\
\text { (rcon0090) }\end{array}$ & The total cash balances due from Federal Reserve Banks. \\
\hline \multirow[t]{4}{*}{ Liquidity } & & & (scaf + chitem + chcoin)/asset \\
\hline & scaf & $\begin{array}{l}\operatorname{rcfd} 1773 \\
(\operatorname{rcon} 1773)\end{array}$ & Total securities designated as available-for-sale, reported at fair (market) value. \\
\hline & chitem & rcon0020 & $\begin{array}{l}\text { Cash items in the process of collection and unposted debits (held in domestic } \\
\text { offices) which are immediately payable upon presentation. }\end{array}$ \\
\hline & chcoin & rcon0080 & Currency and coin held in domestic offices. \\
\hline \multirow[t]{3}{*}{ Loans } & & & (Inlsnet + Inlssale)/asset \\
\hline & Inlsnet & $\begin{array}{l}\text { rcfdb529 } \\
\text { (rconb529) }\end{array}$ & $\begin{array}{l}\text { Total loans and lease financing receivables minus unearned income and loan loss } \\
\text { allowances. }\end{array}$ \\
\hline & Inlssale & $\begin{array}{c}\text { rcfd5369 } \\
\text { (rcon5369) }\end{array}$ & Loans and leases held for sale. \\
\hline
\end{tabular}


Table B1 - Variable descriptions (Cont'd)

\begin{tabular}{|c|c|c|c|}
\hline Variable & $\begin{array}{l}\text { Ref. code of } \\
\text { the SDI (FDIC) } \\
\text { data item }\end{array}$ & $\begin{array}{l}\text { Ref. Codes } \\
\text { Call Reports } \\
\text { FFIEC031 } \\
\text { (FFIEC041) } \\
\end{array}$ & Definition of Variable and Description of the SDI (FDCI) data item \\
\hline \multirow[t]{3}{*}{ Deposits } & & & (trnipcoc + ntripc)/asset \\
\hline & trnipcoc & rconb549 & $\begin{array}{l}\text { Transaction deposits of individuals, partnerships and corporations including } \\
\text { certified and official checks held in domestic offices. }\end{array}$ \\
\hline & ntripc & rconb550 & $\begin{array}{l}\text { Total nontransaction accounts of individuals, partnerships and corporations } \\
\text { (including certified and official checks) held in domestic offices. }\end{array}$ \\
\hline \multirow[t]{2}{*}{ LLP } & & & elnatr/asset \\
\hline & elnatr & riad4230 & $\begin{array}{l}\text { The amount needed to make the allowance for loan and lease losses adequate to } \\
\text { absorb expected loan and lease losses. }\end{array}$ \\
\hline \multirow[t]{2}{*}{$R O A$} & & & netinc/asset \\
\hline & netinc & $\operatorname{riad} 4340$ & $\begin{array}{l}\text { Net interest income plus total noninterest income plus realized gains (losses) on } \\
\text { securities and extraordinary items, less total noninterest expense, loan loss } \\
\text { provisions and income taxes. }\end{array}$ \\
\hline \multirow[t]{2}{*}{ Size } & & & 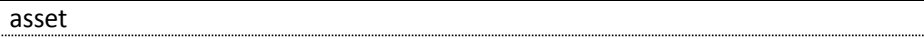 \\
\hline & asset & $\begin{array}{l}\operatorname{rcfd} 2170 \\
(\operatorname{rcon} 2170)\end{array}$ & $\begin{array}{l}\text { The sum of all assets owned by the institution including cash, loans, securities, } \\
\text { bank premises and other assets. It does not include off-balance-sheet accounts. }\end{array}$ \\
\hline
\end{tabular}

Note: This table defines the variables used in the regression analysis in terms of SDI (FDIC) data items, and provides a description for every such item. For every SDI data item the table also gives the corresponding reference codes in the Call Reports of banks with domestic and foreign offices (FFIEC031). The corresponding Call Report codes for banks with domestic offices only (FFIEC041) are reported in brackets, but only when they differ from the FFIEC031 codes. Notice that in some cases there are multiple Call Reports reference codes corresponding to each SDI data item. In these cases Call Reports data are more disaggregated, and the SDI items correspond to the sum of the associated items in the Call Report.

Table B2 - Correlation matrix

\begin{tabular}{|l|ccccccccc|}
\hline & Capital & Interbank & $\begin{array}{c}\text { Fed Funds } \\
\text { Repos }\end{array}$ & $\begin{array}{c}\text { Deposits } \\
\text { Fed }\end{array}$ & LLP & Liquidity & Loans & Deposits & ROA \\
\hline Capital & 1.000 & & & & & & & & \\
Interbank & 0.079 & 1.000 & & & & & & \\
Fed Funds Repos & 0.053 & 0.115 & 1.000 & & & & & \\
Deposits Fed & -0.033 & 0.001 & 0.029 & 1.000 & & & & & \\
LLP & 0.112 & 0.069 & -0.005 & -0.011 & 1.000 & & & & \\
Liquidity & -0.007 & -0.130 & -0.014 & -0.031 & -0.093 & 1.000 & & & \\
Loans & -0.200 & -0.039 & -0.254 & -0.054 & 0.095 & -0.563 & 1.000 & & \\
Deposits & -0.378 & -0.220 & -0.331 & 0.080 & -0.167 & -0.014 & 0.033 & 1.000 & \\
ROA & 0.272 & 0.020 & 0.000 & 0.013 & 0.274 & -0.002 & -0.035 & -0.172 & 1.000 \\
Size & -0.073 & -0.014 & 0.248 & -0.047 & 0.054 & -0.050 & 0.103 & -0.378 & 0.010 \\
\hline
\end{tabular}

Note: This table provides pair-wise unconditional correlations of the variables used in the regression analysis. 


\section{Recent Issues}

No. 44 Lorenz S. Schendel

No. 43 Lorenz S. Schendel

No. 42 Reint Gropp, John Krainer, Elizabeth Laderman

No. 41 Adrian Buss, Raman Uppal, Grigory Vilkov

No. 40 Holger Kraft, Lorenz S. Schendel, Mogens Steffensen

No. 39 H. Evren Damar, Reint Gropp, Adi Mordel

No. 38 Claudia Lambert, Felix Noth, Ulrich Schüwer

No. 37 Deyan Radev

No. 36 Florian Hett, Alexander Schmidt

No. 35 Peter Gomber, Satchit Sagade, Erik Theissen, Moritz Christian Weber, Christian Westheide

No. 34 Nicole Branger, Patrick Grüning, Holger Kraft, Christoph Meinerding, Christian Schlag
Critical IIIness Insurance in Life Cycle Portfolio Problems

Consumption-Investment Problems with Stochastic Mortality Risk

Did Consumers Want Less Debt? Consumer Credit Demand versus Supply in the Wake of the 2008-2009 Financial Crisis

Asset Prices in General Equilibrium with Recursive Utility and Illiquidity Induced by Transaction Costs

Life Insurance Demand under Health Shock Risk

Banks' financial distress, lending supply and consumption expenditure

How do insured deposits affect bank risk? Evidence from the 2008 Emergency Economic Stabilization Act

Systemic Risk and Sovereign Debt in the Euro Area

Bank Rescues and Bailout Expectations: The Erosion of Market Discipline During the Financial Crisis

Competition/Fragmentation in Equities Markets: A Literature Survey

Asset Pricing Under Uncertainty About Shock Propagation 